\title{
Serotonergic Neuroplasticity in Alcohol Addiction
}

\author{
Arnauld Belmer ${ }^{\mathrm{a}, \mathrm{b}, *}$, Omkar L. Patkar ${ }^{\mathrm{a}, \mathrm{b}}$, Kim M. Pitman ${ }^{\mathrm{a}, \mathrm{b}}$ and Selena E. Bartlett ${ }^{\mathrm{a}, \mathrm{b}, *}$ \\ ${ }^{a}$ Translational Research Institute, Queensland University of Technology, Brisbane, Australia \\ ${ }^{\mathrm{b}}$ Institute of Health and Biomedical Innovation (IHBI), Queensland University of Technology, Brisbane, \\ Australia
}

\begin{abstract}
Alcohol addiction is a debilitating disorder producing maladaptive changes in the brain, leading drinkers to become more sensitive to stress and anxiety. These changes are key factors contributing to alcohol craving and maintaining a persistent vulnerability to relapse.

Serotonin (5-Hydroxytryptamine, 5-HT) is a monoamine neurotransmitter widely expressed in the central nervous system where it plays an important role in the regulation of mood. The serotonin system has been extensively implicated in the regulation of stress and anxiety, as well as the reinforcing properties of all of the major classes of drugs of abuse, including alcohol. Dysregulation within the 5-HT system has been postulated to underlie the negative mood states associated with alcohol use disorders.

This review will describe the serotonergic (5-HTergic) neuroplastic changes observed in animal models throughout the alcohol addiction cycle, from prenatal to adulthood exposure. The first section will focus on alcohol-induced 5-HTergic neuroadaptations in offspring prenatally exposed to alcohol and the consequences on the regulation of stress/anxiety. The second section will compare alterations in 5-HT signalling induced by acute or chronic alcohol exposure during adulthood and following alcohol withdrawal, highlighting the impact on the regulation of stress/anxiety signalling pathways. The third section will outline 5-HTergic neuroadaptations observed in various genetically-selected ethanol preferring rat lines. Finally, we will discuss the pharmacological manipulation of the 5-HTergic system on ethanol- and anxiety/stress-related behaviours demonstrated by clinical trials, with an emphasis on current and potential treatments.
\end{abstract}

Keywords: Serotonin, alcohol-related disorders, alcohol addiction, anxiety, stress, depression

Serotonin (5-hydroxytryptamine, 5-HT) is present in almost all organisms from plants to vertebrates. In mammals, 5-HT has been found throughout the body, including the brain, gut, lung, liver, kidney, skin, and platelets. Such a wide distribution indicates that 5-HT is an essential chemical for cell signalling and function in all living animals. In the brain, 5-HT-synthetising neurons are located in the

\footnotetext{
*Correspondence to: Arnauld Belmer and Selena E. Bartlett, Addiction Neuroscience and Obesity Group - Translational Research Institute- Institute of Health and Biomedical Innovation - Queensland University of Technology. 37 Kent St, Woolloongabba, 4102, QLD, Australia. Tel.: +61 73443 7291; Fax: +61 73443 6966; E-mail: arnauld.belmer@qut.edu.au (A. Belmer), Tel.: +61 73443 7238; Fax: +61 73443 6966; E-mail: Selena.bartlett@qut.edu.au (S.E. Bartlett).
}

brainstem raphe nuclei, and the distribution of 5-HT projections is widespread, regulating the activity of almost all brain regions. Thus, 5-HT signalling has been implicated in a variety of brain functions, such as sleep-wake cycle, appetite, locomotion, emotion, hormonal regulation, and as a trophic factor. Furthermore, 5-HT is involved in cognitive functions, including attention, control of impulsivity, coping with stress, social behaviour, value-based decision making, learning and memory.

Serotonin exerts its action via 14 classes of receptors (5-HT1-7). With the exception of 5-HT3 receptors, which gate a cation-permeable ion channel, all 5-HT receptors are coupled to $\mathrm{G}$ proteins. The core features of transduction via 5-HT receptors are well established: the 5-HT1-5 receptor subtypes 
are inhibitors while 5-HT2, 4, 6 and 7 receptor subtypes are activators of neuronal activity. Thus, 5-HT can exert a complex effect on the neuronal output of different brain regions, depending on which 5-HT receptors are expressed, and whether they are expressed by glutamatergic (excitatory) or GABAergic (inhibitory) neurons. Additionally, some receptors, such as the 5-HT1A and $1 \mathrm{~B}$ receptors, have been shown to be also located presynaptically on 5-HT neurons to negatively regulate 5-HTergic neurotransmission [1, 2]. Another main actor in 5-HT signalling is the serotonin transporter (SERT), which is essential to terminate the action of 5-HT in the synapse by reuptaking 5-HT into the terminals.

Hence, serotonin homeostasis is finely regulated and, in humans, alteration in the 5-HT system has been associated with various neuropsychiatric disorders, including stress disorders [3,4], anxiety [5, 6], depression [7-13], bipolar disorders [14] and substance abuse (cocaine [15, 16]; MDMA [17, 18]). These observations suggest that neurochemical adaptations occur in 5-HT neurons in response to environmental or pharmacological stressors. This is supported by studies in rodents showing that both acute and chronic exposure to stress during early life or adulthood alter the functional responses in serotonergic neurons [19], reduce the density of 5-HT innervation in the central, basolateral amygdala and the hippocampus [20], increase the density of 5-HT1A receptors in the basolateral amygdala [21], reduce the expression of 5-HT1A and 5-HT1B receptors in the prefrontal cortex [22] and the hippocampus [23, 24], increase the expression of the 5-HT transporter, SERT, and the 5-HT synthetizing enzyme, TPH2 in the dorsal raphe nucleus (DRN) [25, 26]. Interestingly, comparable neuroplastic changes in brain 5-HT pathways have been observed in alcohol dependence, suggesting that similar mechanisms are involved. Indeed, a growing body of evidence reveals that alcohol use disorders show a high comorbidity with stress, anxiety and depression, in particular during alcohol abstinence following chronic long term exposure.

In this review, we will describe the changes in 5-HT signalling in limbic brain regions induced by prenatal, acute and chronic alcohol exposure, as well as the changes in 5-HT signalling in stress, anxiety and depression pathways induced by alcohol withdrawal. We will then focus on the 5-HTergic adaptations and changes in stress/anxiety-related behaviours observed in various genetically-selected ethanol preferring rodent lines. Finally, we will discuss the involvement of the 5-HTergic system in ethanol- and anxiety/stress-related behaviours, with an emphasis on current and potential treatments.

\section{ANIMAL MODELS OF ALCOHOL CONSUMPTION}

Over several decades, many animal models have been developed to study alcohol dependence. Early studies have employed a "two-bottle choice" procedure in which the animals have continuous access to water and ethanol. Although a slight preference for ethanol develops over drinking sessions, rodents usually limit their consumption to sub-intoxicating levels. Indeed, the taste of ethanol is primarily aversive and rodents do not naturally drink enough ethanol to attain blood ethanol concentration (BEC) equivalent to human alcoholics $(0.8 \mathrm{~g} / \mathrm{L})$. Therefore, different strategies have been used, such as water deprivation, intragastric administration or systemic injection, to allow for the administration of large doses of ethanol, near lethal, that also produce toxicity and do not reflect the neurochemical process of voluntary drinking. Consequently, studies have tried to enhance the motivation to drink ethanol by adding sweeteners which allows for the addition of gradually increasing concentrations of alcohol in ways that avoid the aversiveness of ethanol. However, studies using this "sucrose-fading" procedure failed to produce stable BECs $>0.8 \mathrm{~g} / \mathrm{L}$. Later, studies in rats have shown that removal of the ethanol bottle after 24 hours of exposure increases their consumption when ethanol is reintroduced 24 hours afterwards. This "chronic intermittent model" has been shown to produce high drinking patterns of $5-6 \mathrm{~g} / \mathrm{kg}$ over 24 hours but the BECs were rarely higher than $0.6 \mathrm{~g} / \mathrm{L}$. Based on the observation that rodents ingest most of their daily food and water during the dark phase of their circadian cycle, the "Drinking In the Dark" (DID) model was developed. In this model, animals have a limited access to ethanol, 2 hours per day, 3 hours after the onset of the dark period, 4 days per week and on the 5th day, animals are given 4 hour access. This restricted access, alternating between exposure and withdrawal phases, allows for "binge' ethanol intake in mice (3.5-5 g/kg/2 hrs) and BECs over $1 \mathrm{~g} / \mathrm{L}$, especially in the C57B16 strain, known as alcohol preferrer. Although the mice chronically exposed to the DID for quite a long term (4-6 weeks) reach high BECs, they do not manifest signs of dependence nor ethanol withdrawal symptoms, such as seizures. However, a recent study reported that following 6 weeks of 
exposure, mice exhibit increased anxious/depressive behaviours up to 3 weeks after alcohol withdrawal. To induce ethanol dependence in rodents, the "chronic intermittent exposure" (CIE) model has been used for many years. Animals are acutely or chronically (3 to 4 cycles) exposed to ethanol for 14-16 hours using vapour chambers and clearly reach high BECs (1-2 g/L) and show subsequent escalation of ethanol drinking. However, this procedure requires the coadministration of pyrazole, an inhibitor of the alcohol dehydrogenase, to obtain stable blood EtOH concentrations (BECs) during the entire induction course. Because alcohol vapours are passively administered to the animals and ethanol metabolism is inhibited in this procedure, the validity of this model to reproduce brain neuroplastic changes induced by ethanol dependence in human is questionable.

\section{CONSEQUENCES OF PRENATAL ALCOHOL EXPOSURE ON 5-HT SIGNALLING, STRESS AND ANXIETY DURING EARLY LIFE AND ADULTHOOD (TABLE 1)}

Foetal alcohol spectrum disorders, caused by maternal alcohol consumption during pregnancy, were first described as foetal alcohol syndrome [27]. These disorders are associated with central nervous system malformations (see [28, 29] for review), mental retardation [30,31], cognitive impairments, mood disorders and behavioural dysfunctions that can vary in severity, depending on the amount of alcohol consumption, duration, and timing of prenatal alcohol exposure. Because of its important role in brain development, cognition and the regulation of mood, the 5-HT system has received much attention in the neuroplastic adaptations following prenatal alcohol exposure.

\section{5-HT signalling}

Incomplete neural tube fusion and missing roof and floor plate tissue in the midline have been observed in vivo in foetuses exposed to alcohol, as a result of delayed or prevented formation of the midline and the floor plate tissue [32]. Neurons producing 5-HT are among the earliest to be born in the developing brain and the germinal cells of 5-HT neurons expressed in the raphe adjacent to the midline have been known to rely on trophic factors in midline tissue to differentiate [33]. Thus, alteration in midline formation following prenatal alcohol exposure is likely to alter the development of 5-HT neurons in the offspring's brain. The effect of alcohol on 5-HT neurons begins at neurogenesis (see [29] for review). Animals prenatally exposed to alcohol show reduced density and retarded migration of 5-HT immunoreactive neurons as early as the 13th embryonic day (E13) in the DRN and median raphe (MRN) nuclei in mice [34] and through midgestation (E15) in rats [35] and mice $[34,36,37]$. In vitro studies using a 24 hour treatment of foetal rhombencephalic neurons with ethanol have established that the reduction of 5-HT neurons was probably caused by ethanol-associated apoptosis [38-40], a decreased activity of the phosphatidylinositol 3-kinase (PI3K)/pAkt pro-survival pathway [39] and reduced downstream expression of several $\mathrm{NF}-\kappa \mathrm{B}$ dependent anti-apoptotic genes [40, 41].

The deficit in 5-HT neurons persists into late gestation (E18) [42], in neotates (P5) [43], adolescent (P19-21) [44, 45] and into young adulthood (P35-45) $[42,46]$ in rats and mice, suggesting a long-lasting neuroplastic effect of ethanol on the 5-HT system [45]. Accordingly, reduced levels of 5-HT, its synthesis enzyme TPH2 (Tryptophan hydroxylase) and its degradation product 5-Hydroxyindoleacetic acid (5-HIAA) have been observed in the brain of embryos, neonates and adult animals exposed to ethanol inutero [45, 47-53]. As a consequence of fewer 5-HT neurons in the raphe, embryos in-utero exposed to ethanol show a reduction of 5-HT projections into the medial forebrain bundle (MFB) [36] and fewer 5-HT fibres growing into the ascending pathway in the hypothalamus septal nucleus, frontal and parietal cortices [54]. The forebrain is known to actively develop upon the arrival of 5-HT innervation, this reduction of 5-HT fibre density in ethanol exposed animals likely results in altered growth of brain regions along the ascending 5-HT pathway (hypothalamus, septal nucleus, cortices, and subiculum/hippocampus) [54].

The serotonin transporter (SERT), responsible for the reuptake of 5-HT into presynaptic neurons and nerve terminals, has been shown to be a reliable marker of 5-HT neuron fibres [55]. Short and/or longlasting alterations in SERT expression and function have been demonstrated in the cortex, hippocampus, medial and lateral amygdala, substantia nigra, DRN, and hypothalamus of offspring of dams that consumed alcohol [56-59]. A study in children with foetal alcohol syndrome (FAS) and foetal alcohol effects (FAE) found a similar reduction of SERT expression in the medial frontal cortex [60].

Along with changes in SERT levels, alterations in 5-HT1A receptor expression have been observed in 


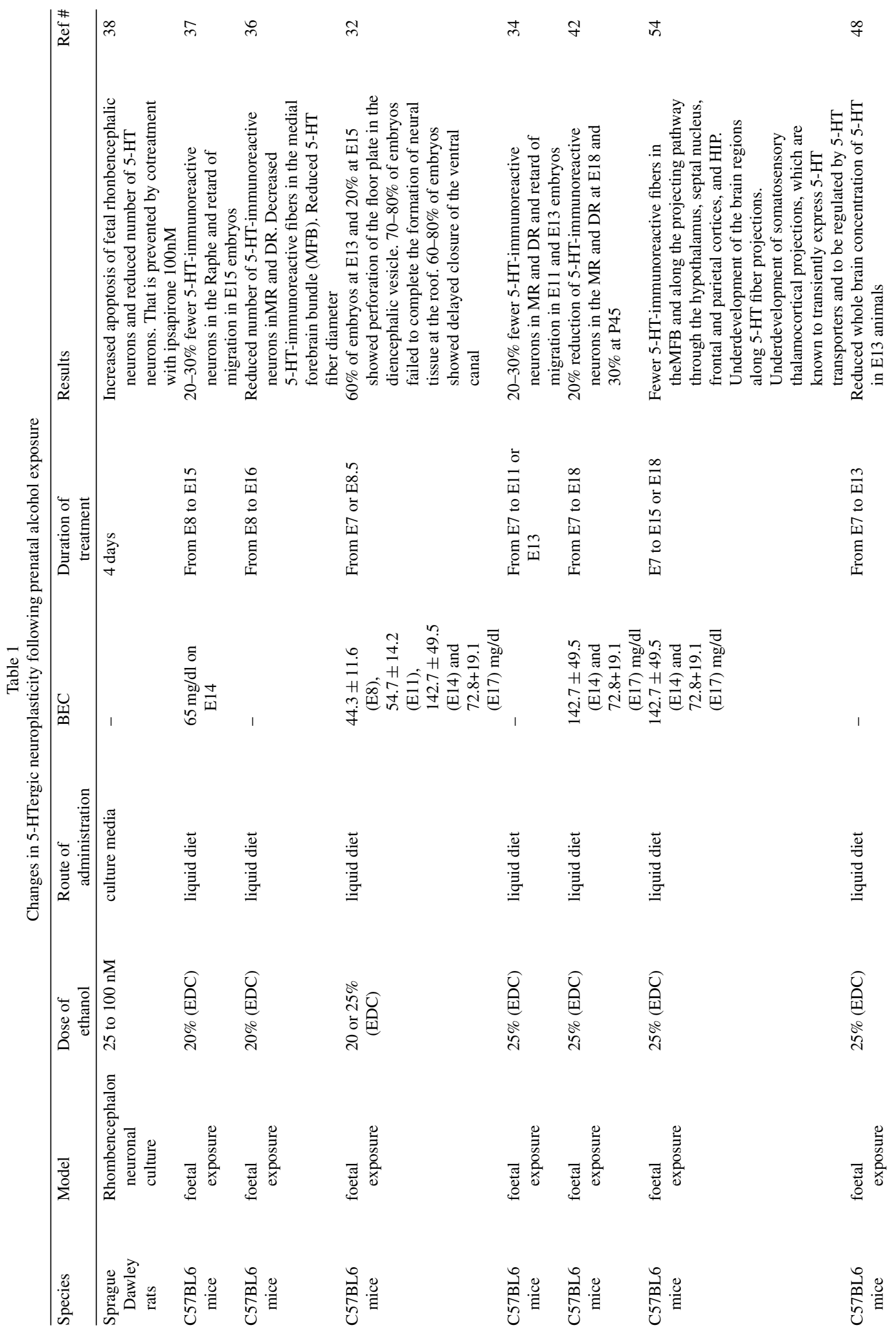


8

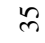

$\stackrel{9}{\forall}$

f $n$

$\stackrel{\infty}{n}$

in

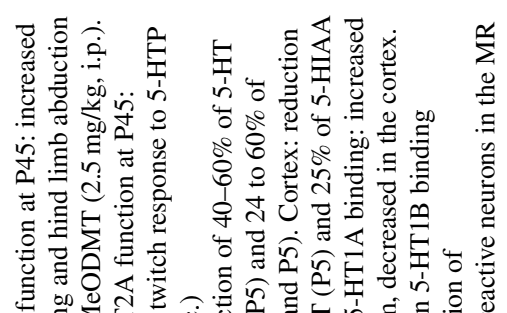

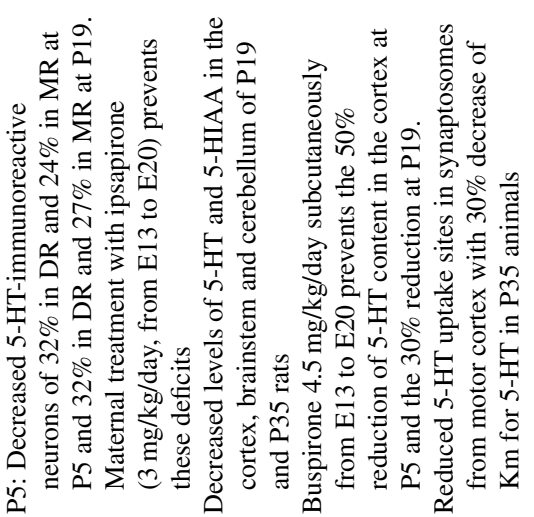

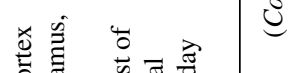

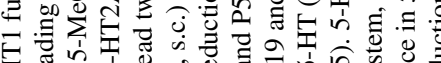

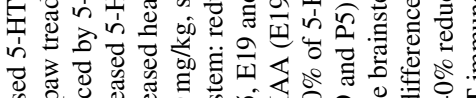

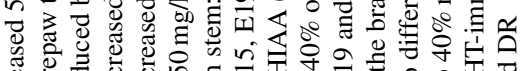

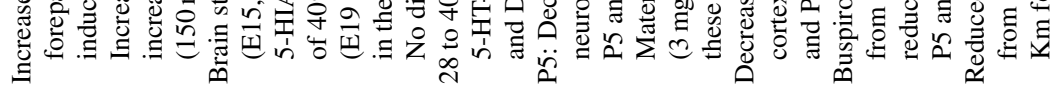
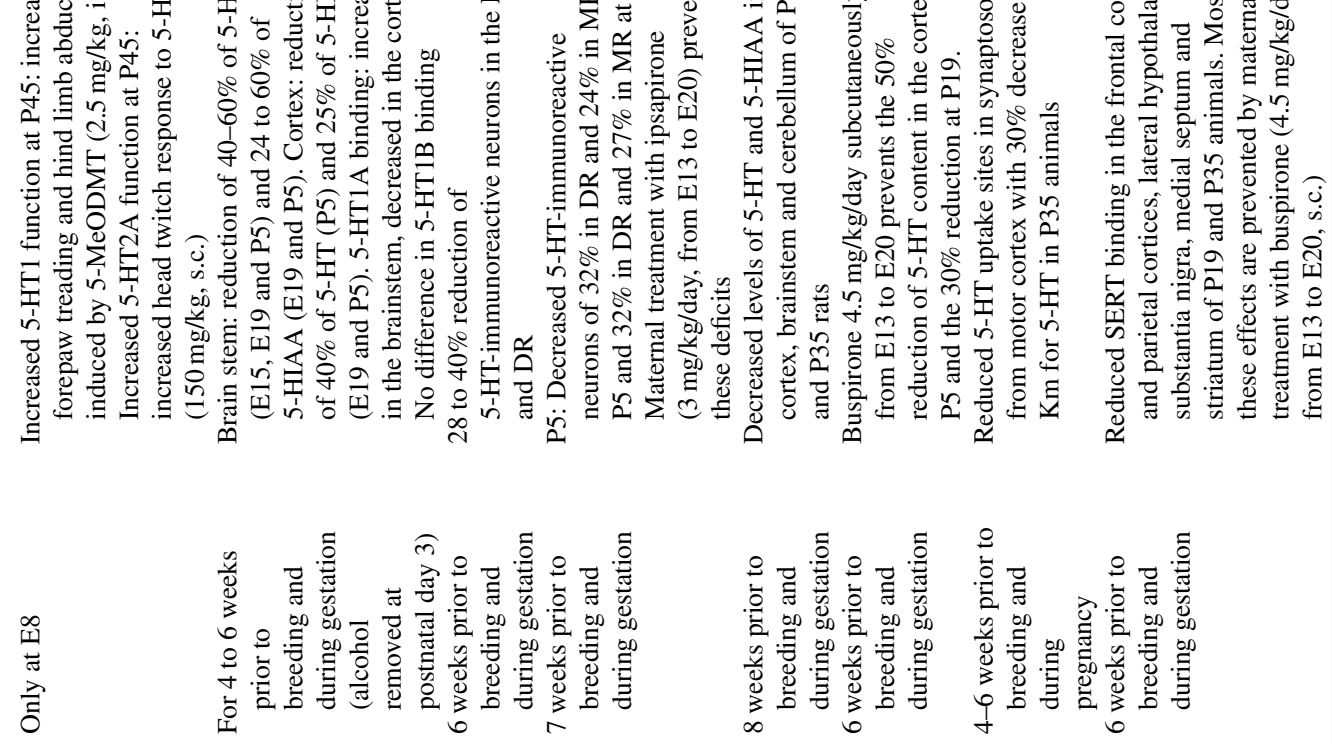

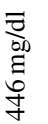
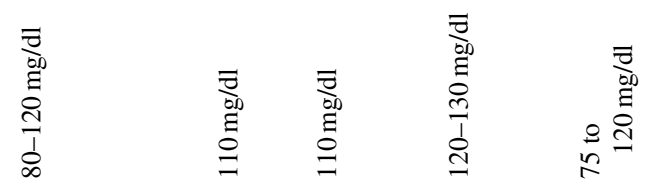

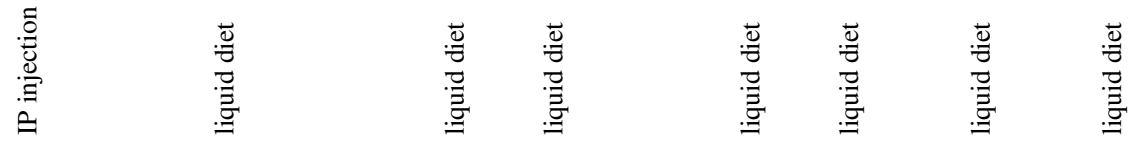

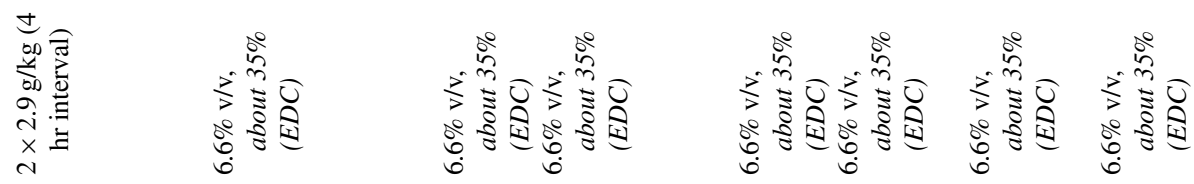

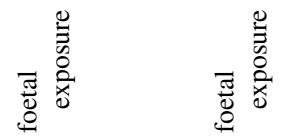

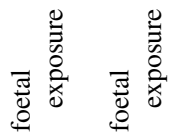

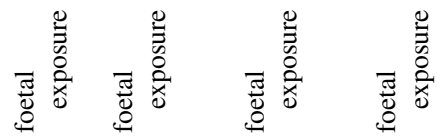

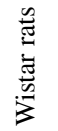

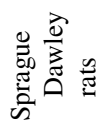

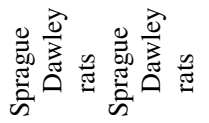

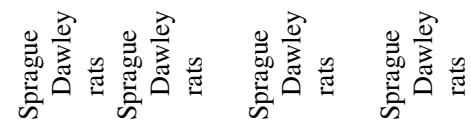




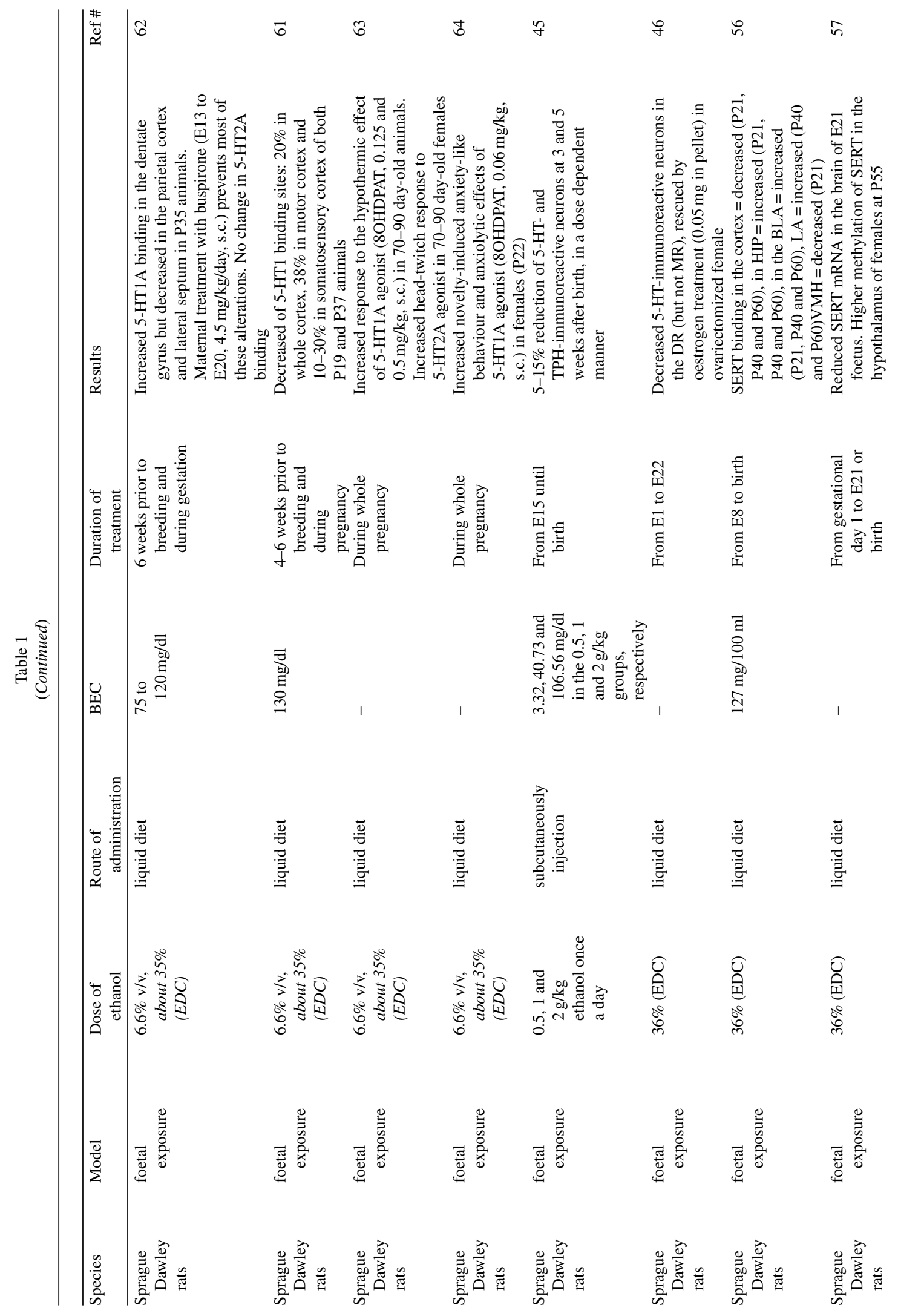



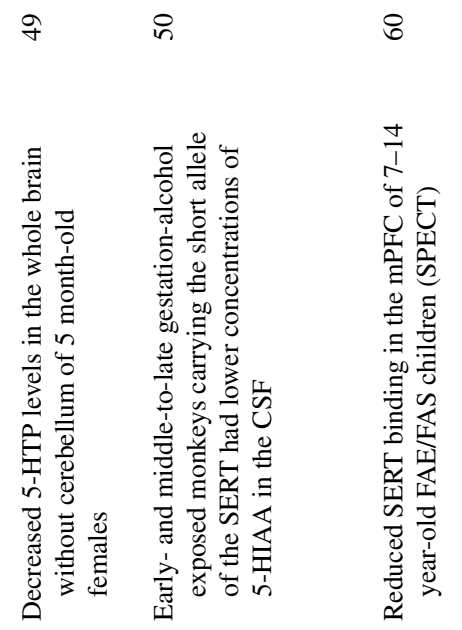

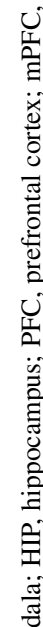

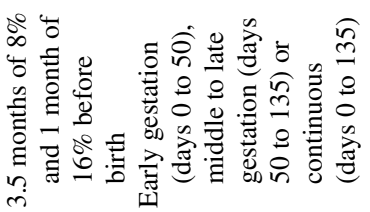

$\overbrace{\substack{n \\ 0 \\ 0}}^{\infty}$

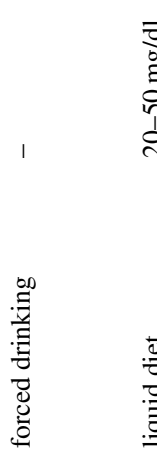

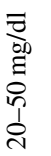

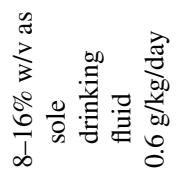

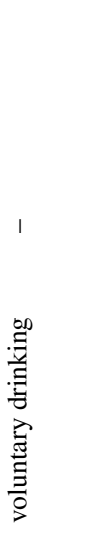

?

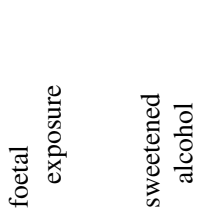

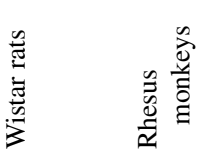

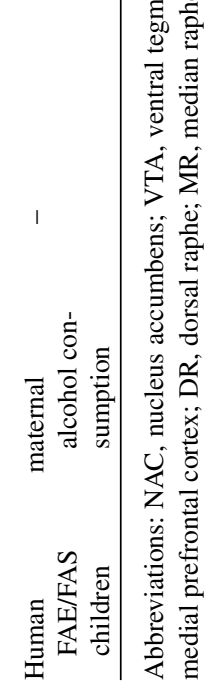


offspring prenatally exposed to alcohol, showing a reduction in the density of binding sites in the motor and somatosensory cortices, lateral septum and an increase in the hippocampus and brainstem of young rats (P5-P35) [35, 61, 62]. Additionally, increased hypothermic and anxiolytic responses to the 5-HT1A receptor agonist 8-OHDPAT as well as increased "wet dog shake" response to the 5-HT2A receptor agonist DOI have been observed in young adult female rats prenatally exposed to alcohol [63-65], revealing a female-specific increase in 5-HT1A/2A receptor sensitivity, which is consistent with the ability of alcohol to upregulate oestrogen levels in females (see [66] for review) that in turn, could upregulate $5-\mathrm{HT} 1 \mathrm{~A} / 2 \mathrm{~A}$ receptor signalling $[67,68]$.

Since the 5-HT1A receptor is expressed both presynaptically, as an autoreceptor in the dorsal raphe to regulate 5-HT neuronal activity, and postsynaptically in limbic brain regions, alterations in 5-HT1A receptor expression and function could play a pivotal role in the pernicious effects of prenatal alcohol exposure on 5-HT pathway. Indeed, in vitro and in vivo treatments during pregnancy with the 5-HT1A receptor partial agonist buspirone or ipsapirone prevent the loss of 5-HT or rhombencephalic neurons [38, 43], the reduction in 5-HT and 5-HIAA levels [53], the alteration in 5-HT1A receptor [62] and SERT expression [59] and the decrease of pAkt [38, 39]. Ipsapirone was also able to increase the expression of NF- $\kappa \mathrm{B}$ dependent genes in foetal rhombencephalic neurons treated with ethanol $[41,69]$. As the 5-HT system has been extensively implicated in the regulation of stress and anxiety, the neuroplastic changes in 5-HT signalling seen with foetal alcohol exposure could alter the regulation of stress- and anxiety-related behaviours, potentially resulting in the development of neuropsychiatric disorders later in life.

\section{Stress and anxiety}

Prenatal ethanol exposure has been shown to induce long-term effects on an organism's ability to respond and adapt to stress, as measured by alterations in hypothalamic-pituitary-adrenal (HPA) function [70-76]. In rodents prenatally exposed to ethanol, altered HPA activity can be observed throughout their lifespan. At birth, basal levels of brain, plasma [77-79], and adrenal [79] corticosterone (CORT), as well as stress-induced increased in plasma CORT levels are augmented [79]. From approximately postnatal days 4 to 14 , which corresponds to the "stress hyporesponsive period" (reviewed in [80]), prenatally exposed animals displayed an even greater HPA hyporesponsiveness, with reduced adrenocorticotropin (ACTH) and CORT responses following a variety of stressors $[77,79,81,82]$. In contrast, in adulthood, prenatally exposed animals exhibit HPA hyper-responsiveness, with increased HPA activity following stress $[70,73,76,83,84]$ and show delayed or deficient recovery to basal levels following chronic or repeated stress [70, 82, 85]. Similarly, HPA hyperresponsiveness is also observed in human infants [15, 86] and in nonhuman primates [87] following prenatal exposure to alcohol.

Although dysfunctions in the HPA axis have been implicated in the pathogenesis of anxiety disorders (reviewed in [88]), studies of basal anxiety in animals prenatally exposed to alcohol have yielded inconsistent results. Some studies have shown an increased basal anxiety in both males and females [64, 89, 90], in other studies only in females [91] or only males [92-94] while others have demonstrated a reduction $[95,96]$ or no difference [97]. However, increased anxiety in prenatally ethanol-exposed animals has been observed in a sex-independent manner following stress exposure $[93,94]$.

Serotonin is a key neurotransmitter involved in HPA regulation [98-101], primarily through $5-\mathrm{HT} 1 \mathrm{~A} / 2 \mathrm{~A}$ receptors [102], and reciprocal interactions between central 5-HT systems and the HPA axis [103, 104]. Additionally, a direct effect of 5-HT on corticotropin releasing hormone (CRH), ACTH, and CORT release [103, 105] have been observed and activation of 5-HT1A/2A receptors activates CRF neurons [106] and increases ACTH and CORT secretion [107]. There is a reciprocal regulatory relationship between 5-HT and the glucocorticoid receptors (GR) [108, 109] and stress induced increases in mineralocorticoid receptor and GR immunoreactivity in the hippocampus are 5-HT dependent [110]. Therefore, changes in 5-HT1A/2A receptor expression and function are likely to be involved, at least in part, in the dysregulation of the stress response $[46,111]$ and the subsequent predisposition to anxiety-like behaviours following prenatal alcohol exposure.

\section{NEUROADAPTATIONS IN 5-HT SIGNALLING FOLLOWING ALCOHOL EXPOSURE (TABLE 2)}

The 5-HT system is not only plastic during embryonic development but also during early life and adulthood (see [112] for review). Therefore, 


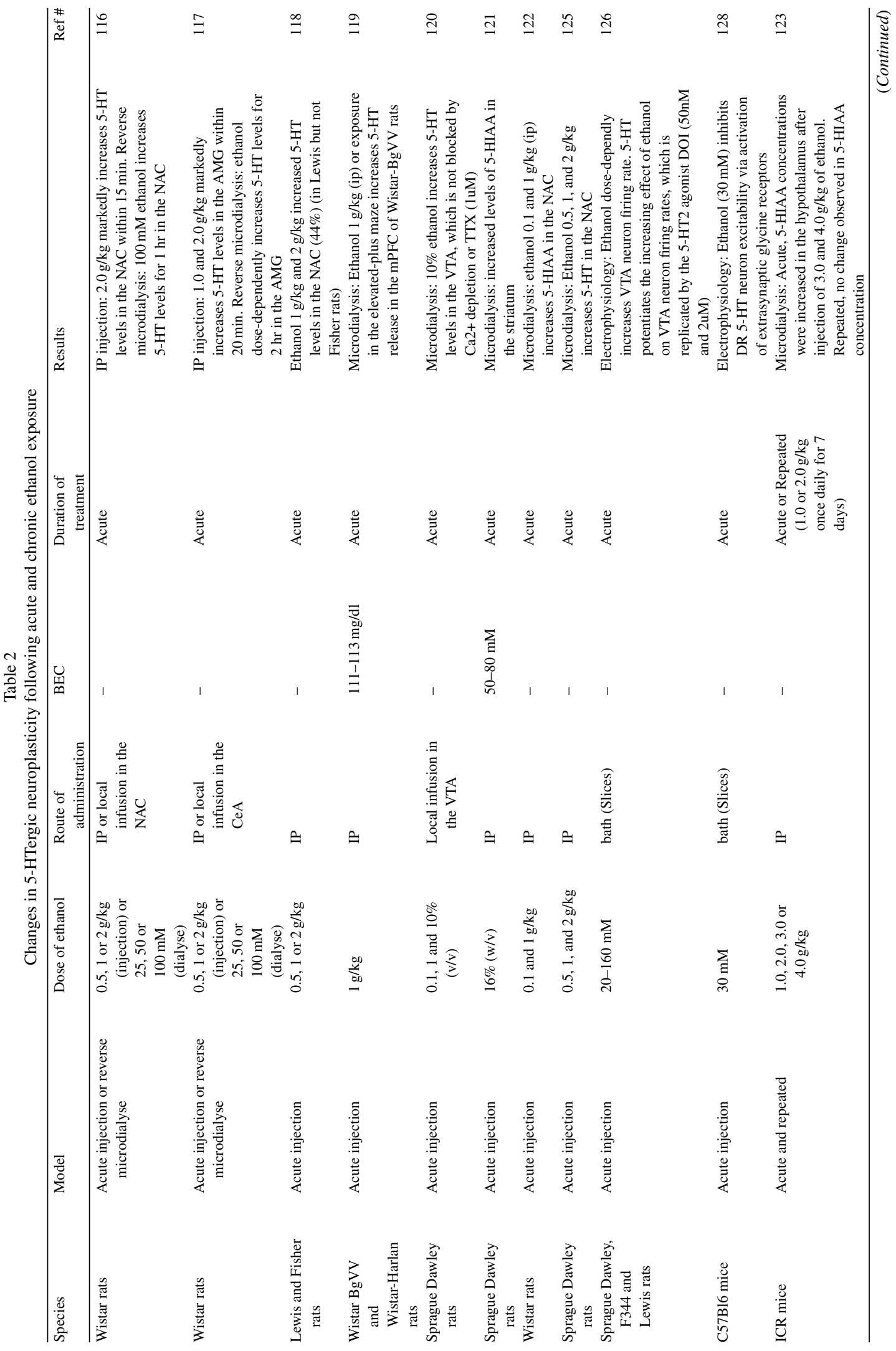




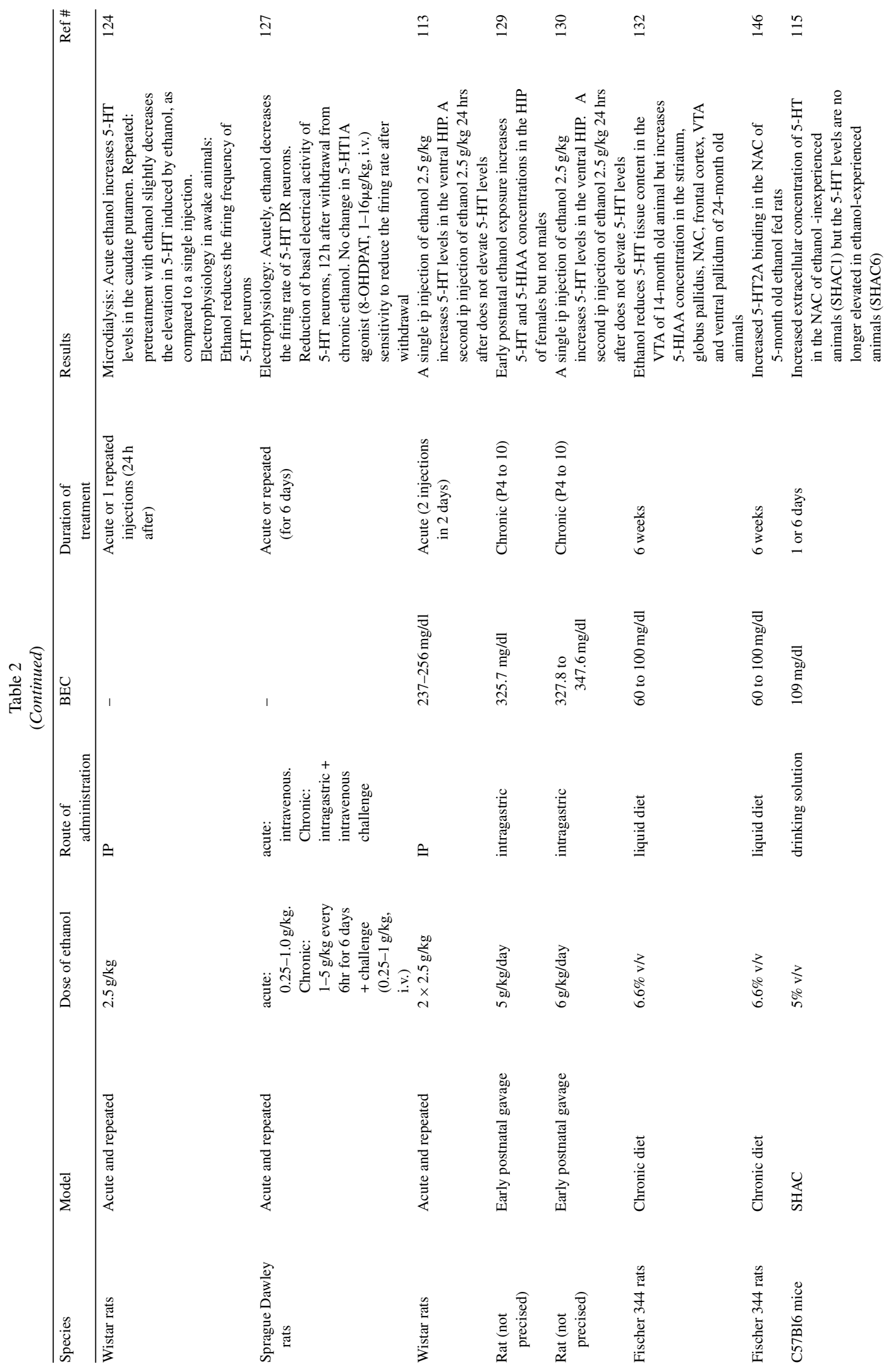


$\stackrel{m}{m}$

$\stackrel{q}{g}$

g

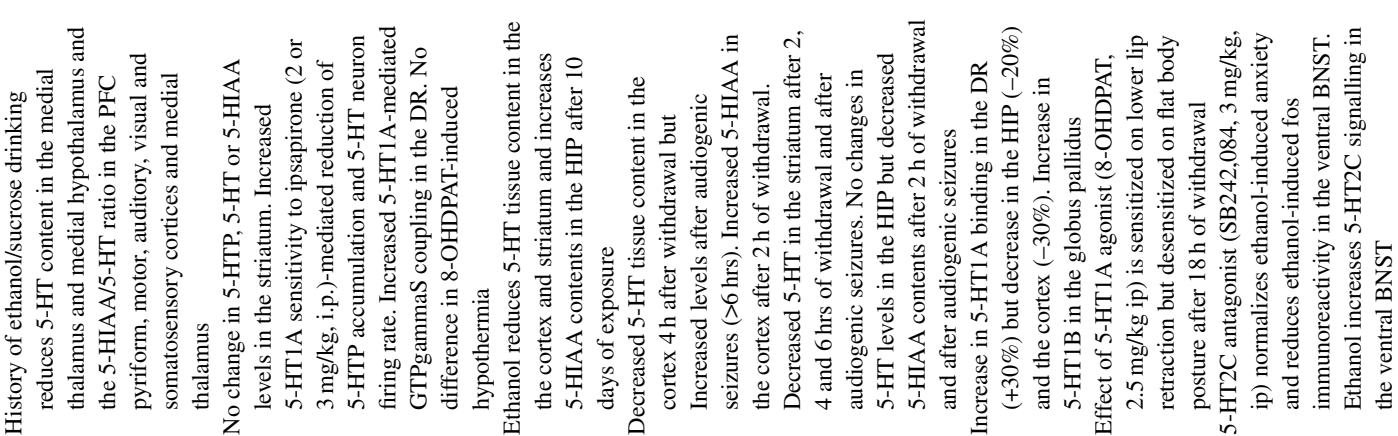

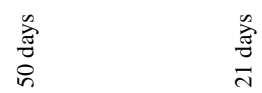

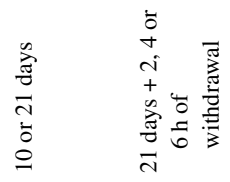

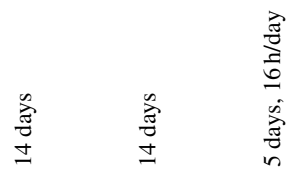

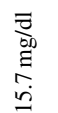

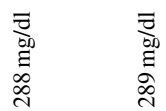

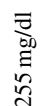

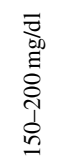

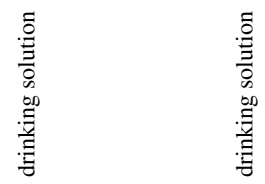

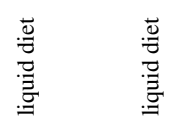

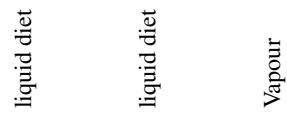

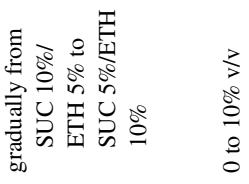

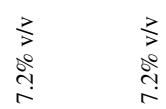

$\begin{array}{ll}\frac{1}{3} & \frac{2}{3} \\ 2 & a^{\circ}\end{array}$
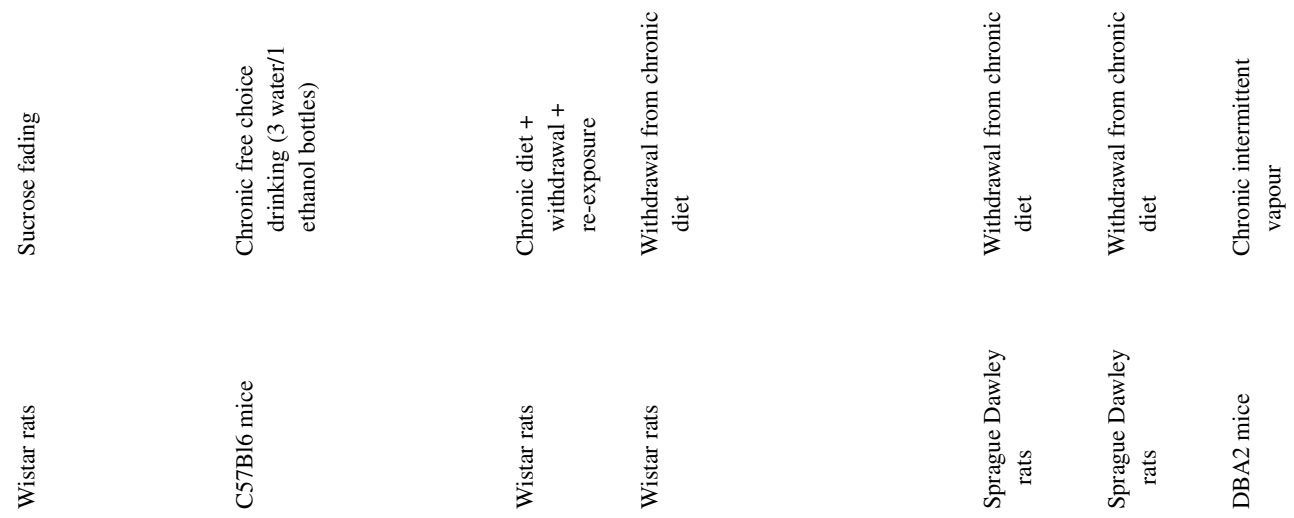

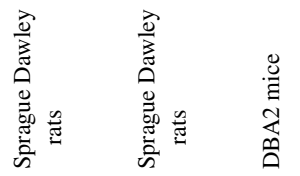




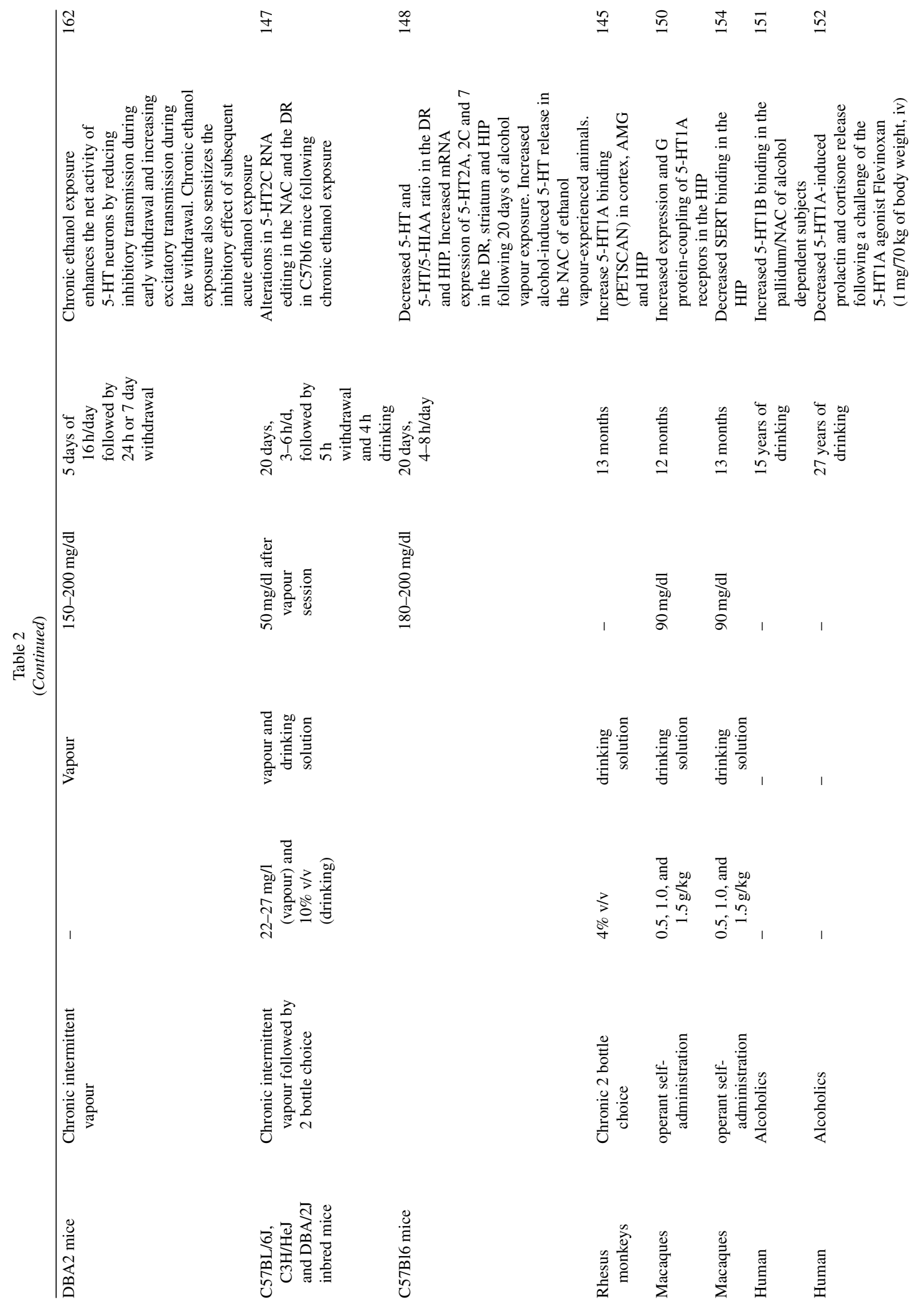




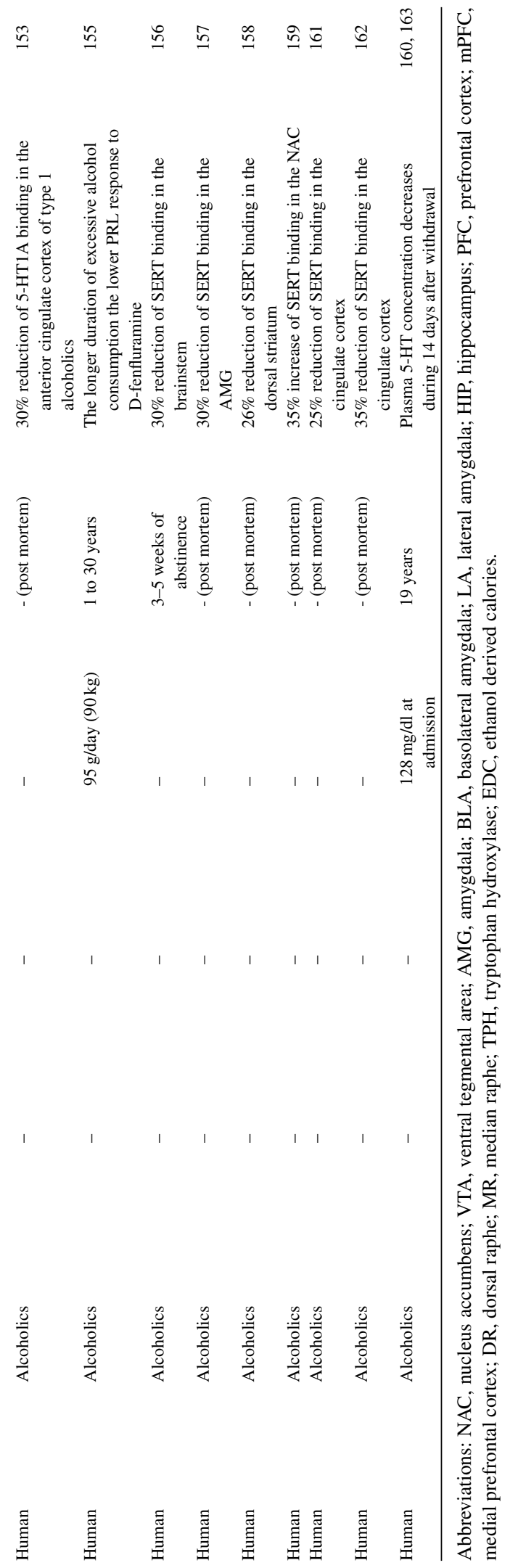


acute stressors that impact 5-HT signalling could lead to long lasting neuroplastic adaptations after chronic exposure. Here, we review the involvement of 5-HT signalling in alcohol dependence in the transition from acute to chronic exposure, following alcohol withdrawal and in relation with alcohol withdrawal-induced stress/anxiety.

\section{Acute exposure}

Microdialysis experiments in rodents have shown that acute systemic injection of ethanol elevates the extracellular levels of 5-HT and/or its metabolite 5-HIAA in multiple brain regions including the nucleus accumbens (NAc), ventral tegmental area (VTA), prefrontal cortex (PFC) and hippocampus (HIP) [113-125]. Similar increases in 5-HT/5-HIAA levels have been observed in the NAc of mice following acute ethanol drinking under the SHAC paradigm [115].

Since 5-HT potentiates alcohol-induced excitation of the dopamine neurons in reward areas of the brain including the NAc and VTA [126], changes in 5-HT neuron activity might be involved in early neurochemical adaptations that promote the reinforcing effects of alcohol and lead to alcohol addiction [115]. However, electrophysiology experiments have shown that acute systemic injection or bath application of ethanol decreases the firing rate of 5-HT neurons by increasing the inhibitory drive in the DRN $[124,127$, 128], suggesting that the stimulatory actions of alcohol on synaptic 5-HT release appear to be mediated by local circuits in the projection areas rather than direct activation of 5-HT neurons.

\section{Chronic alcohol exposure and withdrawal}

Short term chronic alcohol exposure (1 week) during the early phase of postnatal development (first 7-10 days in rat, corresponding to the human third trimester) has been shown to increase the hypothalamic and septal concentration of 5-HT, with a greater effect in females [129, 130].

Chronic alcohol exposure leads to adaptive changes within the brain, presumably to re-establish normal cell function, or homeostasis, in response to continuous alcohol-induced alterations in the mesoaccumbens reward pathway. These neuroadaptations are thought to be involved in the development of tolerance and addiction [131]. Chronic studies have shown that 5-HT levels in the NAc, PFC, globus pallidus, VTA and substantia nigra, are no longer elevated after 1 to
7 weeks of alcohol exposure in comparison to acute ethanol exposure [132-134]. Additionally, reduced 5HT/5-HIAA turnover rate in the NAc suggests 5-HT signalling is decreased [132]. In alcohol dependent rats, 5-HT levels in the NAc, cortex and striatum rapidly decrease during withdrawal [135-137] and are restored by alcohol self-administration [136]. In humans decreased plasma 5-HT levels have been observed in abstinent alcoholics up to 14 days following alcohol withdrawal [138]. Thus, reduced 5-HT neurotransmission after alcohol-withdrawal has been associated with increased stress-induced anxiety, which drives alcohol craving and relapse [139-141].

One study [142] showed the basal activity of 5HT neurons from the DRN is not altered in mice voluntarily drinking alcohol for 3 weeks, suggesting that alteration in 5-HT signalling is not related to changes in 5-HT neurons activity but could rather involve changes in 5-HT receptor signalling. Indeed, the same study demonstrated that 5-HT1A autoreceptors are hypersensitized and their activation by the partial agonist ipsapirone produced a greater inhibition of 5-HT neuron firing in alcohol exposed animals compared to alcohol naive animals [142]. Similarly, increased 5-HT1A autoreceptor expression and function has been observed in the DRN of rats and primates following chronic ethanol comsumption [143-145]. On the other hand, 5-HT1A postsynaptic binding sites were downregulated in the cortex [143], while 5-HT1B/2A/2C receptors were upregulated in the globus pallidus [143], NAc [146-148], bed nucleus of stria terminalis (BNST) [149] and hippocampus. Similar alterations in postsynaptic 5HT1 A and 1B receptors have been reported the cortex and the hippocampus in monkeys [150] or human alcoholics [151-153].

Consistent with a reduced 5-HT neurotransmission, a decreased expression and function of SERT has also been observed in the hippocampus in monkey [154] and in various brain regions in human alcoholics, including the amygdala, the cortex, the dorsal and the ventral striatum[155-161].

Studies on the consequences of withdrawal from chronic alcohol exposure on 5-HT neuron activity have led to inconsistent results. Pistis and co-workers found that 5-HT neuron basal firing was dosedependently reduced in rats, $12 \mathrm{~h}$ after withdrawal of 6 days of intragastric administration of $1-5 \mathrm{~g} / \mathrm{kg}$ of ethanol, every 6 hours [127]. On the contrary, by using vapour chambers in DBA2/J mice, Lowery-Gionta and co-workers recently found that 16 hours/day of ethanol vapour exposure for 6 consecutive days 
enhances the activity and the excitability of DRN neurons 1 to 7 days after the last exposure [162]. However, the exact nature of the recorded neurons was not demonstrated in this study. Because ethanol is known to increase glycinergic and GABAergic signalling in the DRN $[128,163]$ the increased neuronal excitability observed by Lowery-Gionta et al. could be attributed to the recording of interneurons in the DRN, which in turn could reduce 5-HT neuron activity. Further work is then needed to understand how 5-HT neuron activity is modulated by withdrawal from chronic alcohol exposure.

\section{5-HT signalling and alcohol withdrawal-induced stress/anxiety}

A complex relationship exists between alcoholdrinking behaviour and stress/anxiety. Alcohol has anxiety-reducing properties which can relieve stress, while at the same time acting as a stressor and activating the stress response systems. In particular, chronic alcohol exposure and withdrawal can profoundly disturb the function of the HPA axis, which contributes to the sensitization of anxiety-like behaviour, craving for alcohol, and relapse (see [164] for review).

Compelling evidences reveals that CRF neurons within the HPA axis as well as in extrahypothalamic sites, such as the central nucleus of amygdala and BNST, play a pivotal role in the negative emotional processes associated with alcohol withdrawal/craving (see [164-169] for review). Indeed, extracellular CRF levels are elevated in these regions during ethanol withdrawal [170-172] and restored to basal levels by subsequent ethanol intake [173].

The CRF-immunoreactive fibres arising from the amygdala [174] densely innervate the DRN in a topographically organized manner [175-177] and the behavioural effects induced by CRF are thought to be mediated, in part, by CRF actions on 5-HT systems within the brain $[175,178-181]$. Both exposure to a stressor and local infusion of CRF into the DRN have been shown to modulate 5-HT release in forebrain regions, including the PFC, NAc and amygdala [182-185].

Later, studies have shown that both CRF1 and CRF2 receptors are detected in the dorsal raphe nucleus [186-188] and have opposing effects on 5HT release [175, 189, 190]. Corticotropin-releasing factor has a higher affinity for CRF1 receptors when compared to CRF2 receptors [191, 192], and activation of the former normally inhibits 5-HTergic activity in the dorsal raphé $[189,193]$ and 5-HT release in the NAc, striatum and lateral septum [194-196]. In contrast, higher levels of CRF are believed to be required for CRF2 receptor activation. Activation of these receptors normally facilitates 5HTergic activity in the dorsal raphé $[175,189]$ and the release of 5-HT in the NAc, basolateral amygdala, striatum and lateral septum [194-197]. Combined, these studies suggest that CRF has a dual effect in the dorsal raphé nucleus that depends on both CRF1 or CRF2 receptor activation and the CRF concentration.

Alteration in CRF receptor signalling following chronic exposure to a stressor (or alcohol) can impact the regulation of the 5-HT system. In rats chronically exposed to a stressor, relatively high doses of CRF produce a greater increase in the firing rate of 5-HT neurons [198], suggesting a downregulation of CRF1 and/or upregulation of CRF2 signalling following a sustained CRF release induced by chronic stress exposure. Interestingly, similar downregulation of CRF1 receptor expression in various brain regions and upregulation of CRF2 receptor expression in the DRN have been observed in transgenic mice overexpressing CRF [199]. This CRF-5-HT regulation is likely to play an important role in alcohol addiction, as well as in the negative emotional effects of alcohol withdrawal. Systemic injections of both CRF1 antagonist, CRF2 agonist and the 5-HT1A partial agonist buspirone have been shown to reduce ethanol consumption [200-203], ethanol withdrawal-induced sensitization of anxiety-like behaviours [204-210] and stress induced reinstatement of alcohol seeking [211]. Additionally, the infusion of a CRF antagonist into the DRN reduced ethanol drinking [207] and both infusion of a CRF antagonist into the central amygdala (CeA), DRN, and dorsal-BNST and the 5-HT1A partial agonist buspirone into the raphe reduced ethanol-induced anxiety-like behaviours [212, 213] and stress-induced reinstatement of alcohol seeking $[214,215]$. Furthermore, 5-HT2C and 5-HT3 receptors also appear to modulate the mood-altering effects of chronic ethanol intake, as antagonists of these receptors blocked ethanol withdrawal-induced anxiety and stress-induced reinstatement of alcohol seeking [204, 212, 216-218].

\section{NEURONAL ADAPTATIONS IN THE 5-HT SYSTEM IN ALCOHOL PREFERRING RODENT MODELS (TABLE 3)}

To further study alcohol drinking behaviours in rodents, high and low alcohol consuming rodent 


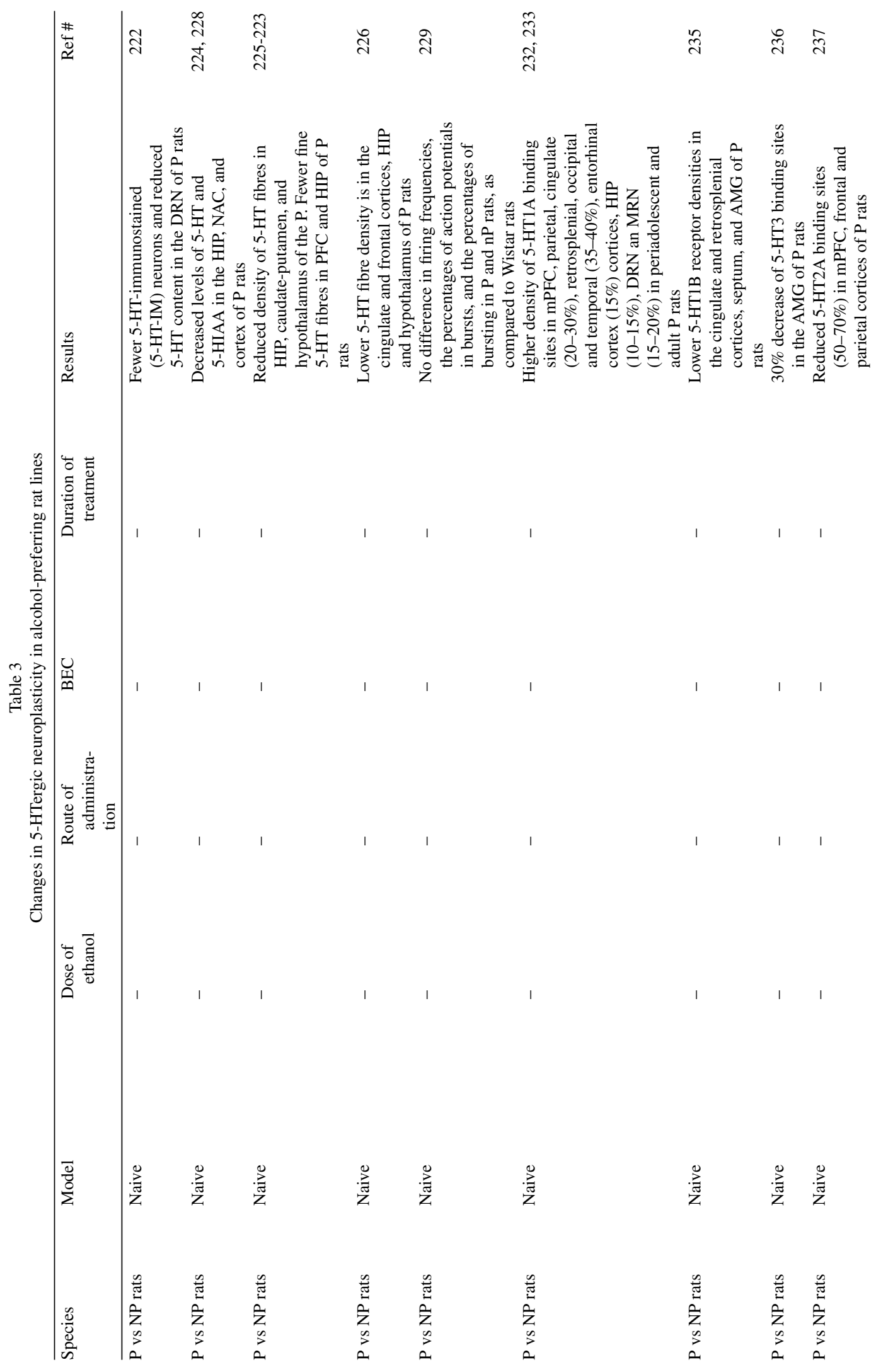


$\stackrel{\infty}{\sim}$

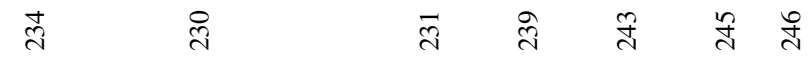

导

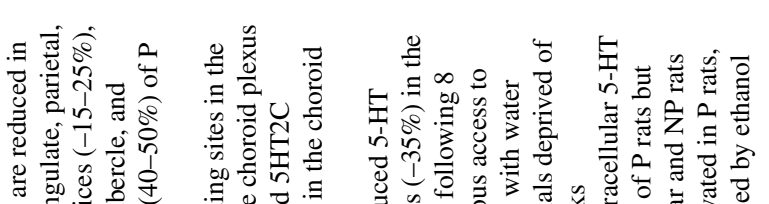

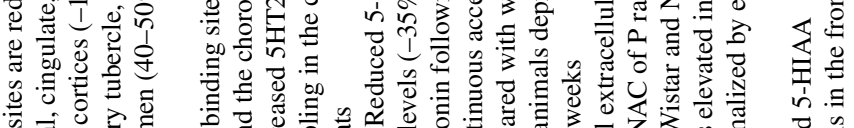

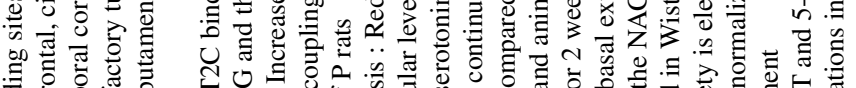

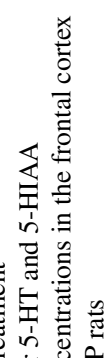

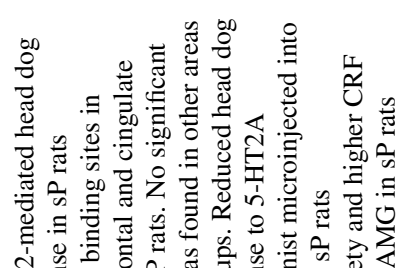

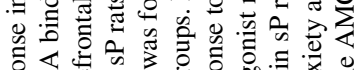

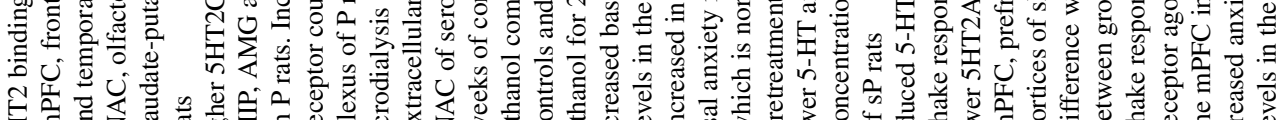

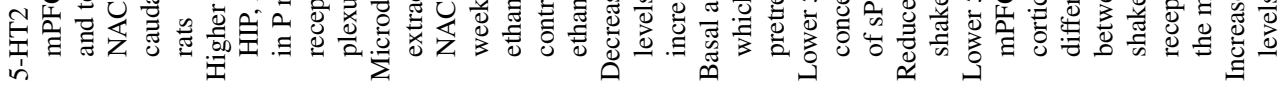

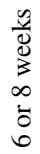

离 卷

竞:

2
8
8

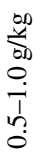

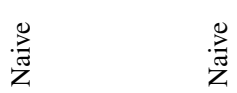

$\frac{0}{0}$
$\frac{0}{0}$
$\frac{0}{0}$
$\frac{0}{0}$
N

$\stackrel{\dot{9}}{\stackrel{\dot{i}}{.}}$

।

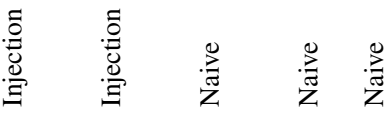

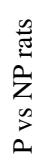

苞

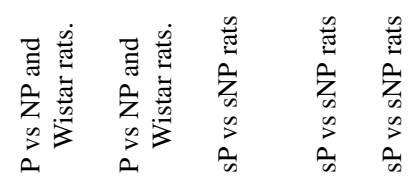




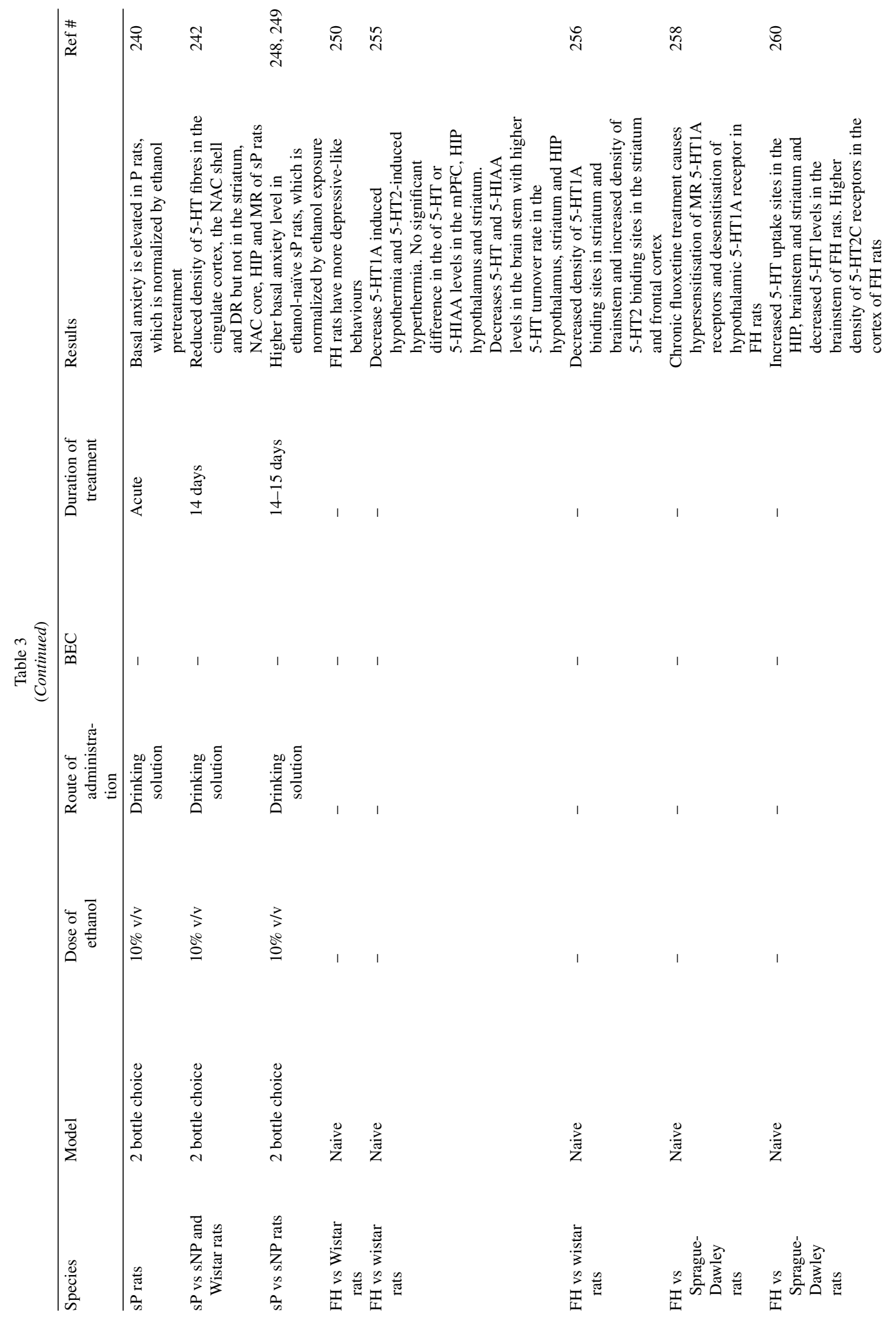


เิ

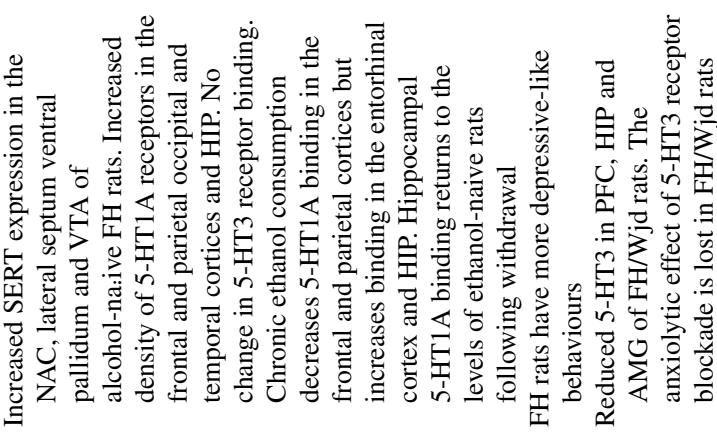

पू के वे

它

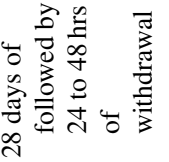

总葛
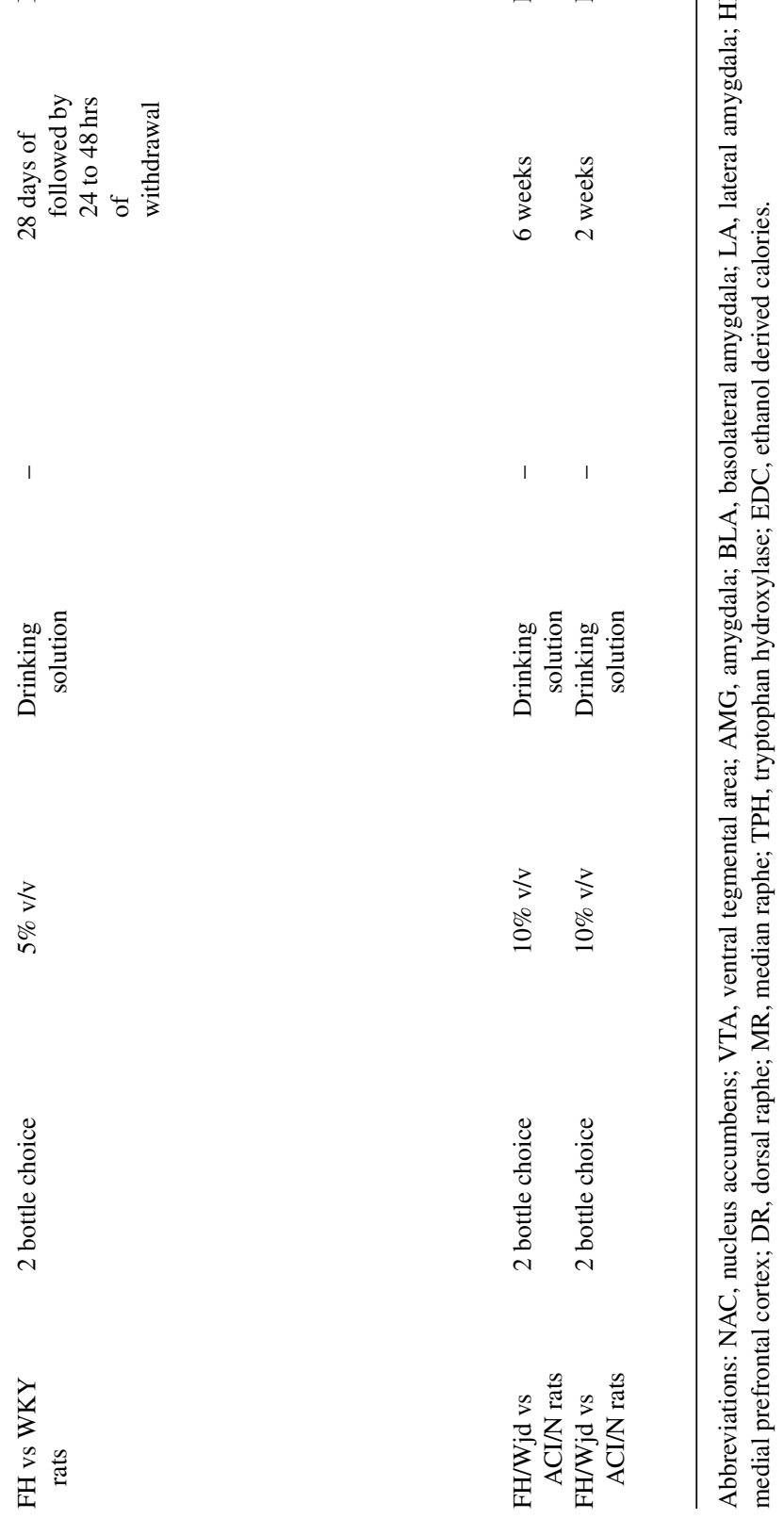
lines have been developed through selective breeding. Some of these rat lines include the alcohol-preferring (P) or non-preferring (nP) rats, Sardinian alcohol preferring (sP) or non-preferring (sNP) and alcohol preferring Fawn-Hooded (FW). Here we present the neuroadaptions in the 5-HT system observed in these rat lines following extensive breeding for alcohol preference.

\section{The alcohol-preferring $(P)$ or non-preferring (nP) rats}

The $\mathrm{P}$ and $\mathrm{nP}$ rats have been the most extensively characterised behaviourally and neurochemically (see [219-221] for review). These rats were selectively bred from a colony of Wistar rats selected for preference or non-preference for $10 \%$ ethanol over water under a 24 hour free choice drinking protocol. The $\mathrm{P}$ rats are capable of consuming $8-10 \mathrm{~g} / \mathrm{kg}$ of ethanol per day and achieve blood ethanol concentrations (BECs) of $2 \mathrm{~g} / \mathrm{L}$.

Interestingly, marked deficiencies in the 5-HT system have been observed in $\mathrm{P}$ rats, as compared to $\mathrm{nP}$ rats. Decreased 5-HT positive neurons in the DRN and MRN [222] as well as reduced 5-HT positive fibres in the prefrontal cortex, NAc, striatum, hippocampus, and hypothalamus [223-225] were shown in $P$ rats. Hence, ethanol-naïve $P$ rats show lower 5HT contents in the NAc, frontal cortex, hypothalamus and hippocampus [226, 227].

These alterations in basal 5-HT signalling are likely to be independent of any compensation on the spontaneous activity of 5-HT neurons [228]. Interestingly, 5-HT levels were further decreased in the NAc and 5-HT3 receptor function was downregulated following 12 weeks of alcohol consumption compared to water-exposed animals [229]. The same study showed that, following 2 weeks of withdrawal, 5-HT turnover was increased in deprived animals as compared to water-exposed or non-deprived animals, suggesting an increased 5-HT clearance which may be due to a compensatory response to higher serotonin release during ethanol withdrawal [229]. Similar effects were observed after intraperitoneal (IP) administration of ethanol in chronically exposed animals: 5-HT levels in the NAc were decreased in P rats but increased in $\mathrm{nP}$ and wistar rats [226, 230] and higher basal 5-HT levels in the NAc were observed after withdrawal [230]. However, 5-HT levels are elevated in the hippocampus in the $\mathrm{P}$ but not the $\mathrm{sP}$ rats following an acute IP ethanol challenge and this ethanol-induced increase in 5-HT overflow in the HIP did not show tolerance after a second challenge [231], as was the case in Wistar rats [113].

Such alterations could be associated with changes in 5-HT receptor signalling. Autoradiography studies have demonstrated an increase of 5-HT1A receptor expression in PFC, NAc and HIP [226, 232, 233] and 5-HT2C receptors in the hippocampus, amygdala, and choroid plexus [234]. Whereas expression of 5-HT1A receptors is upregulated in the DRN and MRN [232], 5-HT1B receptors in the cortex, lateral and medial septum and lateral nucleus of the amygdala [235], 5-HT3 receptor in the amygdala [229, 236], 5-HT2A receptors in the PFC, NAc and striatum $[237,238]$ is downregulated. Interestingly, all these neuroadaptations in 5-HT signalling were associated with a greater degree of anxiety in the $\mathrm{P}$ compared to the $\mathrm{nP}$ rats [239].

\section{The Sardinian alcohol-preferring $(s P)$ and non-preferring $(s N P)$ rats}

Sardinian alcohol-preferring (sP) and alcohol nonpreferring (sNP) rats were selected from a large initial population of Wistar rats individually exposed to a two-bottle free-choice regimen, on the basis of ethanol preference or aversion. The sP rats consistently show a high preference for a $10 \%$ ethanol solution, with their daily ethanol intake averaging $\sim 6 \mathrm{~g} / \mathrm{kg}$ but never reaching an intoxicating level [240, 241].

Similar alterations in the 5-HT system have been reported in the Sardinian alcohol-preferring (sP) and non-preferring (sNP) rats. A significant reduction in the number of 5-HT neurons in the DRN was accompanied by a lower density of 5-HTergic fibres in the cortex and NAc shell [242] and reduced 5-HT and 5-HIAA levels in the PFC of sP rats, compared to sNP and Wistar rats [243, 244]. Lower density of 5HT2A binding sites were also observed in the PFC of $\mathrm{sP}$ rats $[245,246]$. The $\mathrm{sP}$ rats have higher basal levels of CRF in the CeA [247] and a higher innate degree of anxiety than SNP rats, which is reduced to the level of sNP animals after the consumption of alcohol [248, 249].

\section{The Fawn-Hooded (FH) rats}

The FH rats are a Wistar-derived inbred strain originally selected for deficiencies in platelet serotonin storage. Later, these rats were reported to drink high amounts of alcohol, $6 \mathrm{~g} / \mathrm{kg} /$ day of $10 \%$ ethanol $[250,251]$ and exhibit high depression-like behaviour $[250,252,253]$, making this strain a good model 
to study comorbidity of alcoholism and depression [254].

These peripheral abnormalities in the 5-HT system are accompanied by central alterations, including reduced 5-HT levels in the DRN with higher 5-HT/5HIAA turnover in the hypothalamus and striatum but lower in the HIP [255]. Also, SERT binding is increased in the NAc, lateral septum, ventral pallidum, VTA, cortex, HIP, brainstem and striatum but decreased in the hypothalamus [256, 257]. 5-HT1A binding is increased in the frontal cortex and HIP but decreased in the striatum [256] and 5-HT1A function is upregulated in the raphe nuclei [258]. Interestingly, following chronic ethanol consumption, 5-HT1A receptor binding is decreased in the frontal cortex but increased the HIP, and, after withdrawal, HIP 5-HT1A receptor binding was restored to the level of alcohol naïve $\mathrm{FH}$ rats [257].

Furthermore, reduction in 5-HT3 receptor expression was also observed in the frontal cortex, HIP, and amygdala [259] while 5-HT2 receptors displayed a greater binding in the striatum and the frontal cortex but lower in the HIP [256, 260].

\section{CONCLUSION}

It is clear that the neuroplasticity of the 5-HT system is altered in alcohol dependence, which is likely playing a pivotal role in negative emotion-driven craving and relapse. However, alcohol use disorders are complex and multidimensional [261] and the extent of potential abnormalities in 5-HT signalling is likely to vary across patients [262]. A subclassification of alcohol severity has been proposed by Babor and colleagues [263], where type A alcoholism (lower risk/severity) develops during adulthood and is characterized by binge drinking from mild to severe and type B alcoholism (high risk/severity) generally starts during adolescence/early adulthood with severe alcohol abuse remaining stable over time [264].

Study of 5-HT medications for the treatment of alcohol use disorders have led to inconsistent results. Although selective serotonin reuptake inhibitors (SSRIs), antidepressants (Sertraline, Citalopram, Fluvoxamine) have shown promising efficacy for attenuating alcohol consumption [265-270], craving $[265,266]$ and preventing relapse to alcohol consumption [271], other studies have observed that SSRIs were mostly effective in type A patients [262, 272] or in patients with comorbid depressive disor- der and alcohol dependence [273-275], with limited efficacy in type B alcoholics [272].

Clinical trials with buspirone have revealed a promising efficacy of the 5-HT1A partial agonist in reducing alcohol consumption, craving and relapse in alcoholic patients with persistent anxiety [276-280], which could be a useful pharmacological adjunct in the treatment of the psychological symptoms associated with alcohol abstinence. Similarly, the atypical antipsychotic aripiprazole which, aside from its affinity for dopamine receptors, displays a 5-HT1A/2A partial agonist/antagonist activity, was shown to reduce heavy alcohol drinking and craving [281, 282], probably by decreasing visual alcohol-related cue-induced brain activation in alcoholic patients [282, 283]. Additionally, ondansetron, a 5-HT3 receptor antagonist, was shown effective for reducing craving in early onset alcoholics (type B) [284, 285].

Recently, a new class of SSRI antidepressant, namely vortioxetine and vilazodone, has been developed for the treatment of major depressive disorders. This novel class of antidepressant, called serotonin partial agonist-reuptake inhibitor (SPARI) has not only an inhibitory action on 5-HT reuptake (like the classic SSRIs) but also a partial agonist activity at $5-\mathrm{HT} 1 \mathrm{~A} / 1 \mathrm{~B}$ receptors and an antagonist activity 5-HT2A and 5-HT3 receptors. Accordingly, medications acting concurrently on 5-HT reuptake, 5-HT1A, 5-HT2A and 5-HT3 receptors represent great potential for reducing alcohol consumption, craving and relapse in both type A and type B alcoholic patients. However, further work is still required to determine the efficacy of SPARI medications in the treatment of alcohol use disorders.

\section{CONFLICT OF INTEREST}

The authors declare that there is no conflict of interest.

\section{REFERENCES}

[1] Starke K, Göthert M, Kilbinger H. Modulation of neurotransmitter release by presynaptic autoreceptors. Physiol Rev. 1989;69(3):864-989.

[2] Blier P, de Montigny C. Modification of 5-HT neuron properties by sustained administration of the 5-HT1 A agonist gepirone: Electrophysiological studies in the rat brain. Synap N Y N. 1987;1(5):470-80.

[3] Murrough JW, et al. Reduced amygdala serotonin transporter binding in posttraumatic stress disorder. Biol Psychiatry. 2011;70(11):1033-8.

[4] Sullivan GM, et al. Higher in vivo serotonin-1A binding in posttraumatic stress disorder: A pet study with [11C]WAY- 
100635. Depress Anxiety. 2013;30(3):197-206. doi: $10.1002 /$ da.22019

[5] Lanzenberger RR, et al. Reduced serotonin-1A receptor binding in social anxiety disorder. Biol Psychiatry. 2007;61(9):1081-9.

[6] Nash JR, et al. Serotonin 5-HT1A receptor binding in people with panic disorder: Positron emission tomography study. Br J Psychiatry J Ment Sci. 2008;193(3):229-34.

[7] Barton DA, et al. Elevated brain serotonin turnover in patients with depression: Effect of genotype and therapy. Arch Gen Psychiatry. 2008;65(1):38-46.

[8] Drevets WC, et al. PET imaging of serotonin 1A receptor binding in depression. Biol Psychiatry. 1999;46(10):137587.

[9] Drevets WC, et al. Serotonin type-1A receptor imaging in depression. Nucl Med Biol. 2000;27(5):499-507.

[10] Drevets WC, et al. Serotonin-1A receptor imaging in recurrent depression: Replication and literature review. Nucl Med Biol. 2007;34(7):865-77.

[11] Hirvonen J, et al. Decreased brain serotonin 5-HT1A receptor availability in medication-naive patients with major depressive disorder: An in-vivo imaging study using PET and [carbonyl-11C]WAY-100635. Int J Neuropsychopharmacol Off Sci J Coll Int Neuropsychopharmacol CINP. 2008;11(4):465-76.

[12] Meltzer CC, et al. Serotonin 1A receptor binding and treatment response in late-life depression. Neuropsychopharmacol Off Publ Am Coll Neuropsychopharmacol. 2004;29(12):2258-65.

[13] Sargent PA, et al. Brain serotonin1A receptor binding measured by positron emission tomography with [11C]WAY-100635: Effects of depression and antidepressant treatment. Arch Gen Psychiatry. 2000;57(2): 174-80.

[14] Matthews PR, Harrison PJ. A morphometric, immunohistochemical, and in situ hybridization study of the dorsal raphe nucleus in major depression, bipolar disorder, schizophrenia, and suicide. J Affect Disord. 2012;137(13):125-34.

[15] Jacobson SW, Bihun JT, Chiodo LM. Effects of prenatal alcohol and cocaine exposure on infant cortisol levels. Dev Psychopathol. 1999;11(2):195-208.

[16] Mash DC, Staley JK, Izenwasser S, Basile M, Ruttenber AJ. Serotonin transporters upregulate with chronic cocaine use. J Chem Neuroanat. 2000;20(3-4):271-80.

[17] Buchert R, et al. Long-term effects of "ecstasy" use on serotonin transporters of the brain investigated by PET. J Nucl Med Off Publ Soc Nucl Med. 2003;44(3):375-84.

[18] McCann UD, et al. Quantitative PET studies of the serotonin transporter in MDMA users and controls using [11C]McN5652 and [11C]DASB. Neuropsychopharmacol Off Publ Am Coll Neuropsychopharmacol. 2005;30(9):1741-50.

[19] Paul ED, et al. Repeated social defeat increases reactive emotional coping behavior and alters functional responses in serotonergic neurons in the rat dorsal raphe nucleus. Physiol Behav. 2011;104(2):272-82.

[20] Kuramochi M, Nakamura S. Effects of postnatal isolation rearing and antidepressant treatment on the density of serotonergic and noradrenergic axons and depressive behavior in rats. Neuroscience. 2009;163(1):448-55.

[21] Morrison KE, Swallows CL, Cooper MA. Effects of dominance status on conditioned defeat and expression of 5-HT1A and 5-HT2A receptors. Physiol Behav. 2011;104(2):283-90.
[22] Kieran N, Ou X-M, Iyo AH. Chronic social defeat downregulates the 5-HT1A receptor but not Freud-1 or NUDR in the rat prefrontal cortex. Neurosci Lett. 2010;469(3):380-4.

[23] Berton O, Aguerre S, Sarrieau A, Mormede P, Chaouloff F. Differential effects of social stress on central serotonergic activity and emotional reactivity in Lewis and spontaneously hypertensive rats. Neuroscience. 1998;82(1):147-159.

[24] Nakamura K, Kikusui T, Takeuchi Y, Mori Y. Changes in social instigation- and food restriction-induced aggressive behaviors and hippocampal 5HT1B mRNA receptor expression in male mice from early weaning. Behav Brain Res. 2008;187(2):442-8.

[25] Gardner KL, et al. Adverse experience during early life and adulthood interact to elevate tph2 mRNA expression in serotonergic neurons within the dorsal raphe nucleus. Neuroscience. 2009;163(4):991-1001.

[26] Gardner KL, Hale MW, Lightman SL, Plotsky PM, Lowry CA. Adverse early life experience and social stress during adulthood interact to increase serotonin transporter mRNA expression. Brain Res. 2009;1305:47-63.

[27] Jones KL, Smith DW. Recognition of the fetal alcohol syndrome in early infancy. Lancet Lond Engl. 1973;302(7836):999-1001.

[28] Goodlett CR, Horn KH. Mechanisms of alcohol-induced damage to the developing nervous system. Alcohol Res Health J Natl Inst Alcohol Abuse Alcohol. 2001; 25(3):175-84

[29] Goodlett CR, Horn KH, Zhou FC. Alcohol teratogenesis: Mechanisms of damage and strategies for intervention. Exp Biol Med Maywood NJ. 2005;230(6):394-406.

[30] Abel EL. Prenatal effects of alcohol. Drug Alcohol Depend. 1984;14(1):1-10.

[31] Danis RP, Newton N, Keith L. Pregnancy and alcohol. Curr Probl Obstet Gynecol. 1981;4(6):2-48.

[32] Zhou FC, Sari Y, Powrozek T, Goodlett CR, Li T$\mathrm{K}$. Moderate alcohol exposure compromises neural tube midline development in prenatal brain. Dev Brain Res. 2003;144(1):43-55.

[33] Rubenstein JLR. Development of serotonergic neurons and their projections. Biol Psychiatry. 1998;44(3): 145-50.

[34] Zhou FC, Sari Y, Li T-K, Goodlett C, Azmitia EC. Deviations in brain early serotonergic development as a result of fetal alcohol exposure. Neurotox Res. 2002;4(4):337-42.

[35] Druse MJ, Kuo A, Tajuddin N. Effects of in utero ethanol exposure on the developing serotonergic system. Alcohol Clin Exp Res. 1991;15(4):678-84.

[36] Sari Y, Powrozek T, Zhou FC. Alcohol deters the outgrowth of serotonergic neurons at midgestation. J Biomed Sci. 2001;8(1):119-25.

[37] Zhou FC, Sari Y, Zhang JK, Goodlett CR, Li T-K. Prenatal alcohol exposure retards the migration and development of serotonin neurons in fetal C57BL mice. Dev Brain Res. 2001;126(2):147-55.

[38] Druse MJ, et al. The serotonin-1A agonist ipsapirone prevents ethanol-associated death of total rhombencephalic neurons and prevents the reduction of fetal serotonin neurons. Dev Brain Res. 2004;150(2):79-88.

[39] Druse M, Tajuddin NF, Gillespie RA, Le P. Signaling pathways involved with serotonin1A agonist-mediated neuroprotection against ethanol-induced apoptosis of fetal rhombencephalic neurons. Dev Brain Res. 2005; 159(1):18-28. 
[40] Druse MJ, Gillespie RA, Tajuddin NF, Rich M. S100Bmediated protection against the pro-apoptotic effects of ethanol on fetal rhombencephalic neurons. Brain Res. 2007;1150:46-54.

[41] Druse MJ, Tajuddin NF, Gillespie RA, Le P. The effects of ethanol and the serotonin1A agonist ipsapirone on the expression of the serotonin $1 \mathrm{~A}$ receptor and several antiapoptotic proteins in fetal rhombencephalic neurons. Brain Res. 2006;1092(1):79-86.

[42] Sari Y, Zhou FC. Prenatal alcohol exposure causes longterm serotonin neuron deficit in mice. Alcohol Clin Exp Res. 2004;28(6):941-48.

[43] Tajuddin NF, Druse MJ. In utero ethanol exposure decreased the density of serotonin neurons. Maternal Ipsapirone Treatment Exerted a Protective Effect. Brain Res Dev Brain Res. 1999;117(1):91-7.

[44] Tajuddin NF, Druse MJ. A persistent deficit of serotonin neurons in the offspring of ethanol-fed dams: Protective effects of maternal ipsapirone treatment. Dev Brain Res. 2001;129(2):181-8.

[45] Kim E-K, et al. Maternal ethanol administration inhibits 5hydroxytryptamine synthesis and tryptophan hydroxylase expression in the dorsal raphe of rat offspring. Brain Dev. 2005;27(7):472-6.

[46] Sliwowska JH, Song HJ, Bodnar T, Weinberg J. Prenatal Alcohol exposure Results in Long-Term Serotonin Neuron Deficits in Female Rats: Modulatory Role of Ovarian Steroids. Alcohol Clin Exp Res. 2014;38(1): 152-60.

[47] Rathbun W, Druse MJ. Dopamine, serotonin, and acid metabolites in brain regions from the developing offspring of ethanol-treated rats. J Neurochem. 1985;44(1): 57-62.

[48] Sari Y, Hammad LA, Saleh MM, Rebec GV, Mechref Y. Alteration of selective neurotransmitters in fetal brains of prenatally alcohol-treated C57BL/6 mice: Quantitative analysis using liquid chromatography/tandem mass spectrometry. Int J Dev Neurosci Off J Int Soc Dev Neurosci. 2010;28(3):263-9.

[49] Hård E, et al. Impaired maternal behaviour and altered central serotonergic activity in the adult offspring of chronically ethanol treated dams. Acta Pharmacol Toxicol (Copenh). 1985;56(5):347-53.

[50] Schneider ML, Moore CF, Barr CS, Larson JA, Kraemer GW. Moderate prenatal alcohol exposure and serotonin genotype interact to alter CNS serotonin function in rhesus monkeys offspring. Alcohol Clin Exp Res. 2011;35(5):912-20.

[51] Krsiak M, Elis J, Pöschlová N, Masek K. Increased aggressiveness and lower brain serotonin levels in offspring of mice given alcohol during gestation. J Stud Alcohol. 1977;38(9):1696-704.

[52] Elis J, Krsiak M, Pöschlová N, Masek K. The effect of alcohol administration during pregnancy on concentration of noradrenaline, dopamine and 5-hydroxytryptamine in the brain of offspring of mice [proceedings]. Act Nerv Super (Praha). 1976;18(3):220-1.

[53] Tajuddin NF, Druse MJ. Treatment of pregnant alcoholconsuming rats with buspirone: Effects on serotonin and 5-hydroxyindoleacetic acid content in offspring. Alcohol Clin Exp Res. 1993;17(1):110-4.

[54] Zhou FC, Sari Y, Powrozek TA. Fetal alcohol exposure reduces serotonin innervation and compromises development of the forebrain along the serotonergic pathway. Alcohol Clin Exp Res. 2005;29(1):141-9.
[55] Nielsen K, Brask D, Knudsen GM, Aznar S. Immunodetection of the serotonin transporter protein is a more valid marker for serotonergic fibers than serotonin. Synap N Y N. 2006;59(5):270-6.

[56] Zafar H, Shelat SG, Redei E, Tejani-Butt S. Fetal alcohol exposure alters serotonin transporter sites in rat brain. Brain Res. 2000;856(1-2):184-92.

[57] Ngai YF, et al. Prenatal alcohol exposure alters methyl metabolism and programs serotonin transporter and glucocorticoid receptor expression in brain. Am J Physiol - Regul Integr Comp Physiol. 2015:ajpregu.00075.2015.

[58] Druse MJ, Paul LH. Effects of in utero ethanol exposure on serotonin uptake in cortical regions. Alcohol. 1988;5(6):455-9.

[59] Kim JA, Druse MJ. Protective effects of maternal buspirone treatment on serotonin reuptake sites in ethanolexposed offspring. Brain Res Dev Brain Res. 1996; 92(2):190-8.

[60] Riikonen RS, et al. Deep serotonergic and dopaminergic structures in fetal alcoholic syndrome: A study with nor$\beta$-CIT-single-photon emission computed tomography and magnetic resonance imaging volumetry. Biol Psychiatry. 2005;57(12):1565-72.

[61] Tajuddin N, Druse MJ. Chronic maternal ethanol consumption results in decreased serotonergic 5-HT1 sites in cerebral cortical regions from offspring. Alcohol. 1988;5(6):465-70.

[62] Kim J-A, Gillespie RA, Druse MJ. Effects of maternal ethanol consumption and buspirone treatment on 5-HT1A and 5-HT2A receptors in offspring. Alcohol Clin Exp Res. 1997;21(7):1169-78.

[63] Hofmann C, Simms W, Yu W, Weinberg J. Prenatal ethanol exposure in rats alters serotonergic-mediated behavioral and physiological function. Psychopharmacology (Berl). 2002;161(4):379-86.

[64] Hofmann CE, Patyk IA, Weinberg J. Prenatal ethanol exposure: Sex differences in anxiety and anxiolytic response to a 5-HT1A agonist. Pharmacol Biochem Behav. 2005;82(3):549-58.

[65] Fulginiti S, Vigliecca NS, Minetti SA. Acute ethanol intoxication during pregnancy: Postnatal effects on the behavioral response to serotonin agents. Alcohol Fayettev N. 1992;9(6):523-7.

[66] Gill J. The effects of moderate alcohol consumption on female hormone levels and reproductive function. Alcohol Alcohol Oxf Oxfs. 2000;35(5):417-23.

[67] Flügge G, Pfender D, Rudolph S, Jarry H, Fuchs E. 5HT1A-receptor binding in the brain of cyclic and ovariectomized female rats. J Neuroendocrinol. 1999;11(4): 243-9.

[68] Summer BE, Fink G. Estrogen increases the density of 5hydroxytryptamine $(2 \mathrm{~A})$ receptors in cerebral cortex and nucleus accumbens in the female rat. J Steroid Biochem Mol Biol. 1995;54(1-2):15-20.

[69] Lee J-H, Tajuddin NF, Druse MJ. Effects of ethanol and ipsapirone on the expression of genes encoding anti-apoptotic proteins and an antioxidant enzyme in ethanol-treated neurons. Brain Res. 2009;1249: 54-60.

[70] Weinberg J, Taylor AN, Gianoulakis C. Fetal ethanol exposure: Hypothalamic-pituitary-adrenal and beta-endorphin responses to repeated stress. Alcohol Clin Exp Res. 1996;20(1):122-31.

[71] Zhang X, Sliwowska JH, Weinberg J. Prenatal alcohol exposure and fetal programming: Effects on 
neuroendocrine and immune function. Exp Biol Med Maywood NJ. 2005;230(6):376-88.

[72] Halasz I, Aird F, Li L, Prystowsky MB, Redei E. Sexually dimorphic effects of alcohol exposure in utero on neuroendocrine and immune functions in chronic alcohol-exposed adult rats. Mol Cell Neurosci. 1993;4(4):343-53.

[73] Kim CK, Turnbull AV, Lee SY, Rivier CL. Effects of prenatal exposure to alcohol on the release of adenocorticotropic hormone, corticosterone, and proinflammatory cytokines. Alcohol Clin Exp Res. 1999;23(1):52-9.

[74] Lee S, Imaki T, Vale W, RivierC.Effect of prenatal exposure to ethanol on the activity of the hypothalamic-pituitaryadrenal axis of the offspring: Importance of the time of exposure to ethanol and possible modulating mechanisms. Mol Cell Neurosci. 1990;1(2):168-77.

[75] Lee S, Schmidt D, Tilders F, Rivier C. Increased activity of the hypothalamic-pituitary-adrenal axis of rats exposed to alcohol in utero: Role of altered pituitary and hypothalamic function. Mol Cell Neurosci. 2000;16(4):515-28.

[76] Taylor AN, Branch BJ, Liu SH, Kokka N. Longterm effects of fetal ethanol exposure on pituitaryadrenal response to stress. Pharmacol Biochem Behav. 1982;16(4):585-9.

[77] Kakihana R, Butte JC, Moore JA. Endocrine effects of meternal alcoholization: Plasma and brain testosterone, dihydrotestosterone, estradiol, and corticosterone. Alcohol Clin Exp Res. 1980;4(1):57-61.

[78] Taylor AN, Branch BJ, Cooley-Matthews B, Poland RE. Effects of maternal ethanol consumption in rats on basal and rhythmic pituitary-adrenal function in neonatal offspring. Psychoneuroendocrinology. 1982;7(1):49-58.

[79] Weinberg J. Prenatal ethanol exposure alters adrenocortical development of offspring. Alcohol Clin Exp Res. 1989;13(1):73-83

[80] Levine S. Primary social relationships influence the development of the hypothalamic-pituitary-adrenal axis in the rat. Physiol Behav. 2001;73(3):255-60.

[81] Angelogianni P, Gianoulakis C. Ontogeny of the betaendorphin response to stress in the rat: Role of the pituitary and the hypothalamus. Neuroendocrinology. 1989;50(4):372-81.

[82] Taylor AN, Branch BJ, Nelson LR, Lane LA, Poland RE. Prenatal ethanol and ontogeny of pituitary-adrenal responses to ethanol and morphine. Alcohol Fayettev N. 1986;3(4):255-9.

[83] Gabriel KI, Weinberg J. Effects of prenatal ethanol exposure and postnatal handling on conditioned taste aversion. Neurotoxicol Teratol. 2001;23(2):167-76.

[84] Ogilvie KM, Rivier C. Prenatal alcohol exposure results in hyperactivity of the hypothalamic-pituitary-adrenal axis of the offspring: Modulation by fostering at birth and postnatal handling. Alcohol Clin Exp Res. 1997;21(3):424-9.

[85] Kim CK, Giberson PK, Yu W, Zoeller RT, Weinberg J. Effects of prenatal ethanol exposure on hypothalamicpituitary-adrenal responses to chronic cold stress in rats. Alcohol Clin Exp Res. 1999;23(2):301-10.

[86] Ramsay DS, Bendersky MI, Lewis M. Effect of prenatal alcohol and cigarette exposure on two- and six-monthold infants' adrenocortical reactivity to stress. J Pediatr Psychol. 1996;21(6):833-40.

[87] Schneider ML, Moore CF, Kraemer GW, Roberts AD, DeJesus OT. The impact of prenatal stress, fetal alcohol exposure, or both on development: Perspectives from a primate model. Psychoneuroendocrinology. 2002;27(12):285-98
[88] Graeff FG, Zangrossi Junior H. The hypothalamicpituitary-adrenal axis in anxiety and panic. Psychol Neurosci. 2010;3(1):3-8.

[89] Brocardo PS, et al. Anxiety- and depression-like behaviors are accompanied by an increase in oxidative stress in a rat model of fetal alcohol spectrum disorders: Protective effects of voluntary physical exercise. Neuropharmacology. 2012;62(4):1607-18.

[90] Cullen CL, Burne THJ, Lavidis NA, Moritz KM. Low dose prenatal ethanol exposure induces anxiety-like behaviour and alters dendritic morphology in the basolateral amygdala of rat offspring. PloS One. 2013;8(1): e54924.

[91] Wilcoxon JS, Kuo AG, Disterhoft JF, Redei EE. Behavioral deficits associated with fetal alcohol exposure are reversed by prenatal thyroid hormone treatment: A role for maternal thyroid hormone deficiency in FAE. Mol Psychiatry. 2005;10(10):961-71.

[92] Dursun I, Jakubowska-Doğru E, Uzbay T. Effects of prenatal exposure to alcohol on activity, anxiety, motor coordination, and memory in young adult Wistar rats. Pharmacol Biochem Behav. 2006;85(2):345-55.

[93] Hellemans KGC, Verma P, Yoon E, Yu W, Weinberg J. Prenatal alcohol exposure increases vulnerability to stress and anxiety-like disorders in adulthood. Ann N Y Acad Sci. 2008;1144:154-75.

[94] Hellemans KGC, et al. Prenatal alcohol exposure and chronic mild stress differentially alter depressive- and anxiety-like behaviors in male and female offspring. Alcohol Clin Exp Res. 2010;34(4):633-45.

[95] Osborn JA, Kim CK, Steiger J, Weinberg J. Prenatal ethanol exposure differentially alters behavior in males and females on the elevated plus maze. Alcohol Clin Exp Res. 1998;22(3):685-96.

[96] Carneiro LMV, et al. Behavioral and neurochemical effects on rat offspring after prenatal exposure to ethanol. Neurotoxicol Teratol. 2005;27(4):585-92.

[97] Osborn JA, Yu C, Gabriel K, Weinberg J. Fetal ethanol effects on benzodiazepine sensitivity measured by behavior on the elevated plus-maze. Pharmacol Biochem Behav. 1998;60(3):625-33.

[98] Pan L, Gilbert F. Activation of 5-HT1A receptor subtype in the paraventricular nuclei of the hypothalamus induces CRH and ACTH release in the rat. Neuroendocrinology. 1992;56(6):797-802.

[99] Raap DK, Van de Kar LD. Selective serotonin reuptake inhibitors and neuroendocrine function. Life Sci. 1999;65(12):1217-35.

[100] Rittenhouse PA, et al. Evidence that ACTH secretion is regulated by serotonin $2 \mathrm{~A} / 2 \mathrm{C}(5-\mathrm{HT} 2 \mathrm{~A} / 2 \mathrm{C})$ receptors. J Pharmacol Exp Ther. 1994;271(3):1647-55.

[101] Van de Kar LD, et al. 5-HT2A receptors stimulate ACTH, corticosterone, oxytocin, renin, and prolactin release and activate hypothalamic CRF and oxytocin-expressing cells. J Neurosci Off J Soc Neurosci. 2001;21(10):3572-9.

[102] Contesse V, et al. Role of 5-HT in the regulation of the brain-pituitary-adrenal axis: Effects of 5-HT on adrenocortical cells. Can J Physiol Pharmacol. 2000;78(12): 967-83.

[103] Chaouloff F, Baudrie V, Coupry I. Behavioural and biochemical evidence that glucocorticoids are not involved in DOI-elicited 5-HT2 receptor down-regulation. Eur J Pharmacol. 1993;249(1):117-20.

[104] Lanfumey L, Mannoury La Cour C, Froger N, Hamon M. 5-HT-HPA interactions in two models of transgenic mice 
relevant to major depression. Neurochem Res. 2000;25(910):1199-206.

[105] Dinan TG. Serotonin and the regulation of hypothalamicpituitary-adrenal axis function. Life Sci. 1996;58(20): 1683-94.

[106] Mikkelsen JD, Hay-Schmidt A, Kiss A. Serotonergic stimulation of the rat hypothalamo-pituitary-adrenal axis: Interaction between 5-HT1 A and 5-HT2A receptors. Ann N Y Acad Sci. 2004;1018:65-70.

[107] Jørgensen H, Knigge U, Kjaer A, Møller M, Warberg J. Serotonergic stimulation of corticotropin-releasing hormone and pro-opiomelanocortin gene expression. J Neuroendocrinol. 2002;14(10):788-95.

[108] Meijer OC, de Kloet ER. Corticosterone and serotonergic neurotransmission in the hippocampus: Functional implications of central corticosteroid receptor diversity. Crit Rev Neurobiol. 1998;12(1-2):1-20.

[109] Meijer OC, Kortekaas R, Oitzl MS, de KloetER. Acute rise in corticosterone facilitates 5 - $\mathrm{HT}(1 \mathrm{~A})$ receptor-mediated behavioural responses. Eur J Pharmacol. 1998;351(1):714.

[110] Robertson DAF, Beattie JE, Reid IC, Balfour DJK. Regulation of corticosteroid receptors in the rat brain: The role of serotonin and stress. Eur J Neurosci. 2005;21(6): 1511-20.

[111] Hofmann CE, Ellis L, Yu WK, Weinberg J. Hypothalamic-Pituitary-Adrenal Responses to 5-HT1A and 5HT2A/C Agonists Are Differentially Altered in Female and Male Rats Prenatally Exposed to Ethanol. AlcoholClin Exp Res. 2007;31(2):345-55.

[112] Azmitia EC. Serotonin neurons, neuroplasticity, and homeostasis of neural tissue. Neuropsychopharmacology. 1999;21(S1):33S-45S.

[113] Bare DJ, McKinzie JH, McBride WJ. Development of rapid tolerance to ethanol-stimulated serotonin release in the ventral hippocampus. Alcohol Clin Exp Res. 1998;22(6): 1272-6.

[114] McBride WJ. Central nucleus of the amygdala and the effects of alcohol and alcohol-drinking behavior in rodents. Pharmacol Biochem Behav. 2002;71(3):509-15.

[115] Szumlinski KK, et al. Accumbens neurochemical adaptations produced by binge-like alcohol consumption. Psychopharmacology (Berl). 2007;190(4):415-31.

[116] Yoshimoto K, McBride WJ, Lumeng L, Li T-K. Alcohol stimulates the release of dopamine and serotonin in the nucleus accumbens. Alcohol. 1992;9(1):17-22.

[117] Yoshimoto $\mathrm{K}$, et al. Alcohol enhances characteristic releases of dopamine and serotonin in the central nucleus of the amygdala. Neurochem Int. 2000;37(4):369-76.

[118] Selim M, Bradberry CW. Effect of ethanol on extracellular 5-HT and glutamate in the nucleus accumbens and prefrontal cortex: Comparison between the Lewis and Fischer 344 rat strains. Brain Res. 1996;716(1-2):157-64.

[119] Langen B, Dietze S, Fink H. Acute effect of ethanol on anxiety and 5-HT in the prefrontal cortex of rats. Alcohol Fayettev N. 2002;27(2):135-41.

[120] Yan QS, Reith ME, Jobe PC, Dailey JW. Focal ethanol elevates extracellular dopamine and serotonin concentrations in the rat ventral tegmental area. Eur J Pharmacol. 1996;301(1-3):49-57.

[121] Holman RB, Snape BM. Effects of ethanol on 5hydroxytryptamine release from rat corpus striatum in vivo. Alcohol Fayettev N. 1985;2(2):249-53.

[122] Heidbreder C, De Witte P. Ethanol differentially affects extracellular monoamines and GABA in the nucleus accumbens. Pharmacol Biochem Behav. 1993;46(2):47781.

[123] Kaneyuki T, Morimasa T, Shohmori T. Neurotransmitter interactions in the striatum and hypothalamus of mice after single and repeated ethanol treatment. Acta Med Okayama. 1995;49(1):13-17.

[124] Thielen RJ, Morzorati SL, McBride WJ. Effects of ethanol on the dorsal raphe nucleus and its projections to the caudate putamen. Alcohol. 2001;23(3):131-9.

[125] Yan QS. Extracellular dopamine and serotonin after ethanol monitored with 5-minute microdialysis. Alcohol Fayettev N. 1999;19(1):1-7.

[126] Brodie MS, Trifunović RD, Shefner SA. Serotonin potentiates ethanol-induced excitation of ventral tegmental area neurons in brain slices from three different rat strains. J Pharmacol Exp Ther. 1995;273(3):1139-46.

[127] Pistis M, Muntoni AL, Gessa G, Diana M. Effects of acute, chronic ethanol and withdrawal on dorsal raphe neurons: Electrophysiological studies. Neuroscience. 1997;79(1):171-6.

[128] Maguire EP, et al. Extrasynaptic glycine receptors of rodent dorsal raphe serotonergic neurons: A sensitive target for ethanol. Neuropsychopharmacology. 2014;39(5):1232-44.

[129] Kelly SJ. Effects of alcohol exposure and artificial rearing during development on septal and hippocampal neurotransmitters in adult rats. Alcohol Clin Exp Res. 1996;20(4):670-6.

[130] Kelly SJ. Alcohol exposure during development alters hypothalamic neurotransmitter concentrations. J Neural Transm Vienna Austria 1996;103(1-2):55-67.

[131] Koob GF. Alcoholism: Allostasis and beyond. Alcohol Clin Exp Res. 2003;27(2):232-43.

[132] Woods JM, Druse MJ. Effects of chronic ethanol consumption and aging on dopamine, serotonin, and metabolites. J Neurochem. 1996;66(5):2168-78.

[133] Smith JE, Co C, McIntosh S, Cunningham CC. Chronic binge-like moderate ethanol drinking in rats results in widespread decreases in brain serotonin, dopamine, and norepinephrine turnover rates reversed by ethanol intake. J Neurochem. 2008;105(6):2134-55.

[134] Uzbay IT, Usanmaz SE, Akarsu ES. Effects of chronic ethanol administration on serotonin metabolism in the various regions of the rat brain. Neurochem Res. 2000;25(2):257-62

[135] Uzbay IT, Usanmaz SE, Tapanyigit EE, Aynacioglu S, Akarsu ES. Dopaminergic and serotonergic alterations in the rat brain during ethanol withdrawal: Association with behavioral signs. Drug Alcohol Depend. 1998;53(1):3947.

[136] Weiss F, et al. Ethanol self-administration restores withdrawal-associated deficiencies in accumbal dopamine and 5-hydroxytryptamine release in dependent rats. J Neurosci. 1996;16(10):3474-85.

[137] Vasconcelos SMM, et al. Effects of chronic ethanol treatment on monoamine levels in rat hippocampus and striatum. Braz J Med Biol Res Rev Bras Pesqui Médicas E Biológicas Soc Bras Biofísica Al. 2004;37(12): 1839-46.

[138] Patkar AA, et al. Changes in plasma noradrenaline and serotonin levels and craving during alcohol withdrawal. Alcohol Alcohol. 2003;38(3):224-31.

[139] Addolorato G, Leggio L, Abenavoli L, Gasbarrini G. Neurobiochemical and clinical aspects of craving in alcohol addiction: A review. Addict Behav. 2005;30(6):1209-24. 
[140] Ciccocioppo R. The role of serotonin in craving: From basic research to human studies. Alcohol Alcohol. 1999;34(2):244-53.

[141] Renoir T, Pang TY, Lanfumey L. Drug withdrawalinduced depression: Serotonergic and plasticity changes in animal models. Neurosci Biobehav Rev. 2012;36(1):696726.

[142] Kelai S, et al. Chronic voluntary ethanol intake hypersensitizes $5-\mathrm{HT}_{1 \mathrm{~A}}$ autoreceptors in $\mathrm{C} 57 \mathrm{BL} / 6 \mathrm{~J}$ mice. J Neurochem. 2008;107(6):1660-70.

[143] Nevo I, et al. Chronic alcoholization alters the expression of 5-HT1A and 5-HT1B receptor subtypes in rat brain. Eur J Pharmacol. 1995;281(3):229-39.

[144] Kleven M, Ybema C, Carilla E, Hamon M, Koek W. Modification of behavioral effects of 8-hydroxy2-(di-n-propylamino)tetralin following chronic ethanol consumption in the rat: Evidence for the involvement of 5HT1A receptors in ethanol dependence. Eur J Pharmacol. 1995;281(3):219-28.

[145] Hillmer AT, et al. The effects of chronic alcohol selfadministration on serotonin-1 A receptor binding in nonhuman primates. Drug Alcohol Depend. 2014;144:119-26.

[146] Druse MJ, Tajuddin NF, Ricken JD. Effects of chronic ethanol consumption and aging on 5-HT2A receptors and 5-HT reuptake sites. Alcohol Clin Exp Res. 1997;21(7):1157-64.

[147] Watanabe Y, et al. Enhancement of alcohol drinking in mice depends on alterations in RNA editing of serotonin $2 \mathrm{C}$ receptors. Int J Neuropsychopharmacol Off Sci J Coll Int Neuropsychopharmacol CINP. 2014;17(5):739-51.

[148] Yoshimoto K, Watanabe Y, Tanaka M, Kimura M. Serotonin $2 \mathrm{C}$ receptors in the nucleus accumbens are involved in enhanced alcohol-drinking behavior. Eur J Neurosci. 2012;35(8):1368-80.

[149] Marcinkiewcz CA, Dorrier CE, Lopez AJ, Kash TL. Ethanol induced adaptations in 5-HT2c receptor signaling in the bed nucleus of the stria terminalis: Implications for anxiety during ethanol withdrawal. Neuropharmacology. 2015;89:157-67.

[150] Burnett EJ, Grant KA, Davenport AT, Hemby SE, Friedman DP. The effects of chronic ethanol self-administration on hippocampal 5-HT1A receptors in monkeys. Drug Alcohol Depend. 2014;136:135-42.

[151] Hu J, et al. Serotonin 1B Receptor Imaging in Alcohol Dependence. Biol Psychiatry. 2010;67(9):800-3.

[152] Pinto E, et al. Neuroendocrine evaluation of 5-HT1A function in male alcoholic patients. Psychoneuroendocrinology. 2002;27(7):873-9.

[153] Storvik M, Häkkinen M, Tupala E, Tiihonen J. 5-HT1A receptors in the frontal cortical brain areas in cloninger type 1 and 2 alcoholics measured by whole-hemisphere autoradiography. Alcohol Alcohol. 2009;44(1):2-7.

[154] Burnett EJ, Davenport AT, Grant KA, Friedman DP. The effects of chronic ethanol self-administration on hippocampal serotonin transporter density in monkeys. Front Psychiatry. 2012;3. doi:10.3389/fpsyt.2012.00038

[155] Berggren U, Eriksson M, Fahlke C, Balldin J. Is long-term heavy alcohol consumption toxic for brain serotonergic neurons? Relationship between years of excessive alcohol consumption and serotonergic neurotransmission. Drug Alcohol Depend. 2002;65(2):159-65.

[156] Heinz A, et al. Reduced central serotonin transporters in alcoholism. Am J Psychiatry. 1998;155(11):1544-9.

[157] Storvik M, Tiihonen J, Haukijärvi T, Tupala E. Amygdala serotonin transporters in alcoholics measured by whole hemisphere autoradiography. Synap N Y N. 2007;61(8):629-36

[158] Storvik M, Tiihonen J, Haukijärvi T, Tupala E. Lower serotonin transporter binding in caudate in alcoholics. Synap N Y N. 2006;59(3):144-51.

[159] Storvik M, Tiihonen J, Haukijärvi T, Tupala E. Nucleus accumbens serotonin transporters in alcoholics measured by whole-hemisphere autoradiography. Alcohol Fayettev N. 2006;40(3):177-84.

[160] Kärkkäinen $\mathrm{O}$, et al. Lower [3H]Citalopram binding in brain areas related to social cognition in alcoholics. Alcohol Alcohol Oxf Oxfs. 2015;50(1):46-50.

[161] Mantere T, et al. Serotonin transporter distribution and density in the cerebral cortex of alcoholic and nonalcoholic comparison subjects: A whole-hemisphere autoradiography study. Am J Psychiatry. 2002;159(4):599-606.

[162] Lowery-Gionta EG, Marcinkiewcz CA, Kash TL. Functional alterations in the dorsal raphe nucleus following acute and chronic ethanol exposure. Neuropsychopharmacology. 2014;40(3):590-600. doi:10.1038/npp.2014.205

[163] Lemos JC, et al. Stress-hyperresponsive WKY rats demonstrate depressed dorsal raphe neuronal excitability and dysregulated CRF-mediated responses. Neuropsychopharmacology. 2011;36(4):721-34.

[164] Breese GR, Sinha R, Heilig M. Chronic alcohol neuroadaptation and stress contribute to susceptibility for alcohol craving and relapse. Pharmacol Ther. 2011;129(2): 149-71.

[165] Heilig M, Koob GF. A key role for corticotropinreleasing factor in alcohol dependence. Trends Neurosci. 2007;30(8):399-406.

[166] Koob GF. Chapter 3 - Neurocircuitry of alcohol addiction: Synthesis from animal models. Handbook of Clinical Neurology, Alcohol and the Nervous System., ed Pfefferbaum EVS and A (Elsevier), 2014, pp. 33-54.

[167] Koob GF, Zorrilla EP. Neurobiological mechanisms of addiction: Focus on corticotropin-releasing factor. Curr Opin Investig Drugs Lond Engl 2000. 2010;11(1):63-71.

[168] Lowery EG, Thiele TE. Pre-clinical evidence that corticotropin-releasing factor (CRF) receptor antagonists are promising targets for pharmacological treatment of alcoholism. CNS Neurol Disord Drug Targets. 2010;9(1):77-86.

[169] Zorrilla EP, Logrip ML, Koob GF. Corticotropin releasing factor: A key role in the neurobiology of addiction. Front Neuroendocrinol. 2014;35(2):234-44. doi:10.1016/j.yfrne.2014.01.001

[170] Merlo Pich E, et al. Increase of extracellular corticotropinreleasing factor-like immunoreactivity levels in the amygdala of awake rats during restraint stress and ethanol withdrawal as measured by microdialysis. J Neurosci Off J Soc Neurosci. 1995;15(8):5439-47.

[171] Menzaghi F, et al. The role of corticotropin-releasing factor in the anxiogenic effects of ethanol withdrawal. Ann N Y Acad Sci. 1994;739(1):176-184.

[172] Silberman Y, et al. Neurobiological mechanisms contributing to alcohol-stress-anxiety interactions. Alcohol. 2009;43(7):509-19.

[173] Olive MF, Koenig HN, Nannini MA, Hodge CW. Elevated extracellular CRF levels in the bed nucleus of the stria terminalis during ethanol withdrawal and reduction by subsequent ethanol intake. Pharmacol Biochem Behav. 2002;72(1-2):213-20.

[174] Gray TS. Amygdaloid CRF pathways. Role in autonomic, neuroendocrine, and behavioral responses to stress. Ann N Y Acad Sci. 1993;697:53-60. 
[175] Kirby LG, Rice KC, Valentino RJ. Effects of corticotropinreleasing factor on neuronal activity in the serotonergic dorsal raphe nucleus. Neuropsychopharmacology. 2000;22(2):148-62.

[176] Sakanaka M, Shibasaki T, Lederis K. Corticotropin releasing factor-like immunoreactivity in the rat brain as revealed by a modified cobalt-glucose oxidasediaminobenzidine method. J Comp Neurol. 1987;260(2): 256-98.

[177] Swanson LW, Sawchenko PE, Rivier J, Vale WW. Organization of ovine corticotropin-releasing factor immunoreactive cells and fibers in the rat brain: An immunohistochemical study. Neuroendocrinology. 1983;36(3): 165-86.

[178] Forster GL, et al. Corticotropin-releasing factor in the dorsal raphe elicits temporally distinct serotonergic responses in the limbic system in relation to fear behavior. Neuroscience. 2006;141(2):1047-55.

[179] Hammack SE, et al. The role of corticotropin-releasing hormone in the dorsal raphe nucleus in mediating the behavioral consequences of uncontrollable stress. J Neurosci Off J Soc Neurosci. 2002;22(3):1020-6.

[180] Spiga F, Lightman SL, Shekhar A, Lowry CA. Injections of urocortin 1 into the basolateral amygdala induce anxiety-like behavior and c-Fos expression in brainstem serotonergic neurons. Neuroscience. 2006;138(4): 1265-76.

[181] Staub DR, Evans AK, Lowry CA. Evidence supporting a role for corticotropin-releasing factor type 2 (CRF2) receptors in the regulation of subpopulations of serotonergic neurons. Brain Res. 2006;1070(1):77-89.

[182] Price ML. Corticotropin -releasing factor modulation of serotonin release: Neurochemical and behavioral studies in the rat. Diss Available Pro Quest. 2000;1-186.

[183] Kirby LG, Lucki I. Interaction between the forced swimming test and fluoxetine treatment on extracellular 5-hydroxytryptamine and 5-hydroxyindoleacetic acid in the rat. J Pharmacol Exp Ther. 1997;282(2): 967-76.

[184] Kirby LG, Allen AR, Lucki I. Regional differences in the effects of forced swimming on extracellular levels of 5hydroxytryptamine and 5-hydroxyindoleacetic acid. Brain Res. 1995;682(1-2):189-96.

[185] Kirby LG, Chou-Green JM, Davis K, Lucki I. The effects of different stressors on extracellular 5-hydroxytryptamine and 5-hydroxyindoleacetic acid. Brain Res; 1997;760(12):218-30.

[186] Commons KG, Connolley KR, Valentino RJ. A neurochemically distinct dorsal raphe-limbic circuit with a potential role in affective disorders. Neuropsychopharmacol Off Publ Am Coll Neuropsychopharmacol. 2003;28(2):206-15.

[187] Funk D, Li Z, Shaham Y, Lê AD. Effect of blockade of corticotropin-releasing factor receptors in the median raphe nucleus on stress-induced c-fos mRNA in the rat brain. Neuroscience. 2003;122(1):1-4.

[188] Van Pett K, et al. Distribution of mRNAs encoding CRF receptors in brain and pituitary of rat and mouse. J Comp Neurol. 2000;428(2):191-212.

[189] Pernar L, Curtis AL, Vale WW, Rivier JE, Valentino RJ. Selective activation of corticotropin-releasing factor-2 receptors on neurochemically identified neurons in the rat dorsal raphe nucleus reveals dual actions. J Neurosci Off J Soc Neurosci. 2004;24(6):1305-11.

[190] Valentino RJ, Liouterman L, Van Bockstaele EJ. Evidence for regional heterogeneity in corticotropin-releasing factor interactions in the dorsal raphe nucleus. J Comp Neurol. 2001;435(4):450-63.

[191] Grigoriadis DE, Lovenberg TW, Chalmers DT, Liaw C, De Souze EB. Characterization of corticotropin-releasing factor receptor subtypes. Ann N Y Acad Sci. 1996;780: 60-80.

[192] Grigoriadis DE, et al. 125I-Tyro-sauvagine: A novel high affinity radioligand for the pharmacological and biochemical study of human corticotropin-releasing factor 2 alpha receptors. Mol Pharmacol. 1996;50(3):679-86.

[193] Hammack SE, Pepin JL, DesMarteau JS, Watkins LR, Maier SF. Low doses of corticotropin-releasing hormone injected into the dorsal raphe nucleus block the behavioral consequences of uncontrollable stress. Behav Brain Res. 2003;147(1-2):55-64.

[194] Lukkes JL, Forster GL, Renner KJ, Summers CH. Corticotropin-releasing factor 1 and 2 receptors in the dorsal raphé differentially affect serotonin release in the nucleus accumbens. Eur J Pharmacol. 2008;578(2-3):18593.

[195] Price ML, Lucki I. Regulation of serotonin release in the lateral septum and striatum by corticotropin-releasing factor. J Neurosci Off J Soc Neurosci. 2001;21(8): 2833-41.

[196] Price ML, Curtis AL, Kirby LG, Valentino RJ, Lucki I. Effects of corticotropin-releasing factor on brain serotonergic activity. Neuropsychopharmacology. 1998;18(6):492-502.

[197] Amat J, et al. Microinjection of urocortin 2 into the dorsal raphe nucleus activates serotonergic neurons and increases extracellular serotonin in the basolateral amygdala. Neuroscience. 2004;129(3):509-19.

[198] Lowry CA, Rodda JE, Lightman SL, Ingram CD. Corticotropin-releasing factor increases in vitro firing rates of serotonergic neurons in the rat dorsal raphe nucleus: Evidence for activation of a topographically organized mesolimbocortical serotonergic system. J Neurosci. 2000;20(20):7728-36.

[199] Korosi A, et al. Distribution and expression of CRF receptor 1 and 2 mRNAs in the CRF over-expressing mouse brain. Brain Res. 2006;1072(1):46-54.

[200] Hedlund L, Wahlström G. Buspirone as an inhibitor of voluntary ethanol intake in male rats. Alcohol Alcohol. 1996;31(2):149-56.

[201] Hedlund L, Wahlström G. Acute and long term effects of buspirone treatments on voluntary ethanol intake in a rat model of alcoholism. Alcohol Clin Exp Res. 1999;23(5):822-7.

[202] Lowery EG, et al. CRF-1 antagonist and CRF-2 agonist decrease binge-like ethanol drinking in C57BL/6J mice independent of the HPA axis. Neuropsychopharmacol Off Publ Am Coll Neuropsychopharmacol. 2010;35(6):124152.

[203] Correia D, et al. Reduction of ethanol intake by corticotropin-releasing factor receptor-1 antagonist in "heavy-drinking" mice in a free-choice paradigm. Psychopharmacology (Berl). 2015;232(15):2731-9.

[204] Breese GR, Overstreet DH, Knapp DJ, Navarro M. Prior multiple ethanol withdrawals enhance stressinduced anxiety-like behavior: Inhibition by CRF1- and benzodiazepine-receptor antagonists and a 5-HT1areceptor agonist. Neuropsychopharmacology. 2005;30(9): 1662-9.

[205] Breese GR, Knapp DJ, Overstreet DH. Stress sensitization of ethanol withdrawal-induced reduction in social 
interaction: Inhibition by CRF-1 and benzodiazepine receptor antagonists and a 5-HT1A-receptor agonist. Neuropsychopharmacol Off Publ Am Coll Neuropsychopharmacol. 2004;29(3):470-82.

[206] Wills TA, Knapp DJ, Overstreet DH, Breese GR. Sensitization, duration, and pharmacological blockade of anxiety-like behavior following repeated ethanol withdrawal in adolescent and adult rats. Alcohol Clin Exp Res. 2009;33(3):455-63.

[207] Hwa LS, et al. Dissociation of $\mu$-opioid receptor and CRF-R1 antagonist effects on escalated ethanol consumption and mPFC serotonin in C57BL/6J mice. Addict Biol. 2014;21(1):111-24. doi:10.1111/adb. 12189

[208] Baldwin HA, Rassnick S, Rivier J, Koob GF, Britton KT. CRF antagonist reverses the "anxiogenic" response to ethanol withdrawal in the rat. Psychopharmacology (Berl). 1991;103(2):227-32.

[209] Overstreet DH, Knapp DJ, Breese GR. Modulation of multiple ethanol withdrawal-induced anxiety-like behavior by CRF and CRF1 receptors. Pharmacol Biochem Behav. 2004;77(2):405-13.

[210] Lal H, Prather PL, Rezazadeh SM. Anxiogenic behavior in rats during acute and protracted ethanol withdrawal: Reversal by buspirone. Alcohol Fayettev N. 1991;8(6):467-71.

[211] Marinelli PW, et al. The CRF1 receptor antagonist antalarmin attenuates yohimbine-induced increases in operant alcohol self-administration and reinstatement of alcohol seeking in rats. Psychopharmacology (Berl). 2007;195(3):345-55.

[212] Overstreet DH, Knapp DJ, Angel RA, Navarro M, Breese GR. Reduction in repeated ethanol-withdrawal-induced anxiety-like behavior by site-selective injections of 5HT1A and 5-HT2C ligands. Psychopharmacology (Berl). 2006;187(1):1-12.

[213] Huang MM, et al. Corticotropin-releasing factor (CRF) sensitization of ethanol withdrawal-induced anxiety-like behavior is brain site specific and mediated by CRF-1 receptors: Relation to stress-induced sensitization. J Pharmacol Exp Ther. 2010;332(1):298-307.

[214] Le AD, Harding S, Juzytsch W, Fletcher PJ, Shaham Y. The role of corticotropin-releasing factor in the median raphe nucleus in relapse to alcohol. J Neurosci. 2002;22(18):7844-9.

[215] Lê AD, Funk D, Coen K, Li Z, Shaham Y. Role of corticotropin-releasing factor in the median raphe nucleus in yohimbine-induced reinstatement of alcohol seeking in rats. Addict Biol. 2013;18(3):448-51.

[216] Knapp DJ, Overstreet DH, Moy SS, Breese GR. SB242084, flumazenil, and CRA1000 block ethanol withdrawal-induced anxiety in rats. Alcohol Fayettev N. 2004;32(2):101-11.

[217] Lê AD, et al. Effects of dexfenfluramine and 5-HT3 receptor antagonists on stress-induced reinstatement of alcohol seeking in rats. Psychopharmacology (Berl). 2006;186(1):82-92.

[218] Overstreet DH, Knapp DJ, Moy SS, Breese GR. A 5-HT1A agonist and a 5-HT2c antagonist reduce social interaction deficit induced by multiple ethanol withdrawals in rats. Psychopharmacology (Berl). 2003;167(4):344-52.

[219] Lumeng L, Li TK. The development of metabolic tolerance in the alcohol-preferring P rats: Comparison of forced and free-choice drinking of ethanol. Pharmacol Biochem Behav. 1986;25(5):1013-20.
[220] McBride WJ, Li TK. Animal models of alcoholism: Neurobiology of high alcohol-drinking behavior in rodents. Crit Rev Neurobiol. 1998;12(4):339-69.

[221] Murphy JM, et al. Phenotypic and genotypic characterization of the Indiana University rat lines selectively bred for high and low alcohol preference. Behav Genet. 2002;32(5):363-88.

[222] Zhou FC, Pu CF, Murphy J, Lumeng L, Li T-K. Serotonergic neurons in the alcohol preferring rats. Alcohol. 1994;11(5):397-403.

[223] Zhou FC, Bledsoe S, Lumeng L, Li TK. Immunostained serotonergic fibers are decreased in selected brain regions of alcohol-preferring rats. Alcohol Fayettev N. 1991;8(6):425-31.

[224] Zhou FC, Bledsoe S, Lumeng L, Li TK. Reduced serotonergic immunoreactive fibers in the forebrain of alcohol-preferring rats. Alcohol Clin Exp Res. 1994;18(3):571-9.

[225] Zhou FC, Lumeng L, Li TK. Quantitative immunocytochemical evaluation of serotonergic innervation in alcoholic rat brain. Neurochem Int. 1995;26(2):135-43.

[226] McBride WJ, Murphy JM, Lumeng L, Li T-K. Serotonin, dopamine and GABA involvement in alcohol drinking of selectively bred rats. Alcohol. 1990;7(3):199-205.

[227] Strother WN, Lumeng L, Li T-K, McBride WJ. Dopamine and serotonin content in select brain regions of weanling and adult alcohol drinking rat lines. Pharmacol Biochem Behav. 2005;80(2):229-37.

[228] Morzorati SL, Johnson TB. Serotonergic neuronal activity in the dorsal raphe nucleus of selectively bred alcohol-preferring and alcohol-nonpreferring rats and unselected wistar rats. Alcohol Clin Exp Res. 1999;23(8): 1362-7.

[229] Thielen RJ, et al. Ethanol drinking and deprivation alter dopaminergic and serotonergic function in the nucleus accumbens of alcohol-preferring rats. J Pharmacol Exp Ther. 2004;309(1):216-25.

[230] Smith AD, Weiss F. Ethanol exposure differentially alters central monoamine neurotransmission in alcoholpreferring versus -nonpreferring rats. J Pharmacol Exp Ther. 1999;288(3):1223-8.

[231] Thielen RJ, Bare DJ, McBride WJ, Lumeng L, Li T-K. Ethanol-stimulated serotonin release in the ventral hippocampus: An absence of rapid tolerance for the alcohol-preferring $\mathrm{P}$ rat and insensitivity in the alcohol-nonpreferring NP rat. Pharmacol Biochem Behav. 2002;71(1-2):111-7.

[232] McBride WJ, Guan X-M, Chernet E, Lumeng L, Li T-K. Regional serotonin1A receptors in the CNS of alcoholpreferring and -nonpreferring rats. Pharmacol Biochem Behav. 1994;49(1):7-12.

[233] Strother WN, Lumeng L, Li T-K, McBride WJ. Regional CNS densities of serotonin $1 \mathrm{~A}$ and dopamine D2 receptors in periadolescent alcohol-preferring $\mathrm{P}$ and alcoholnonpreferring NP rat pups. Pharmacol Biochem Behav. 2003;74(2):335-42.

[234] Pandey SC, Lumeng L, Li TK. Serotonin2C receptors and serotonin $2 \mathrm{C}$ receptor-mediated phosphoinositide hydrolysis in the brain of alcohol-preferring and alcohol-nonpreferring rats. Alcohol Clin Exp Res. 1996;20(6):1038-42.

[235] McBride WJ, et al. Regional CNS densities of monoamine receptors in alcohol-naive alcohol-preferring $\mathrm{P}$ and nonpreferring NP rats. Alcohol. 1997;14(2):141-8. 
[236] Ciccocioppo R, Ge J, Barnes NM, Cooper SJ. Central 5HT3 receptors in $\mathrm{P}$ and in AA alcohol-preferring rats: An autoradiographic study. Brain Res Bull. 1998;46(4): 311-5.

[237] Ciccocioppo R, Ge J, Barnes NM, Cooper SJ. Autoradiographic mapping of brain 5-HT2A binding sites in $\mathrm{P}$ and in AA alcohol-preferring rats. Brain Res Bull. 1997;44(1):33-7.

[238] McBride WJ, Chernet E, Rabold JA, Lumeng L, Li TK. Serotonin-2 receptors in the CNS of alcohol-preferring and -nonpreferring rats. Pharmacol Biochem Behav. 1993;46(3):631-6.

[239] Stewart RB, Gatto GJ, Lumeng L, Li TK, Murphy JM. Comparison of alcohol-preferring $(\mathrm{P})$ and nonpreferring (NP) rats on tests of anxiety and for the anxiolytic effects of ethanol. Alcohol Fayettev N. 1993;10(1):1-10.

[240] Colombo G. ESBRA-Nordmann 1996 Award Lecture: Ethanol drinking behaviour in Sardinian alcoholpreferring rats. Alcohol Alcohol Oxf Oxfs. 1997;32(4): 443-53.

[241] Lobina C, et al. Constant absolute ethanol intake by Sardinian alcohol-preferring rats independent of ethanol concentrations. Alcohol Alcohol Oxf Oxfs. 1997;32(1):19-22

[242] Casu MA, Pisu C, Lobina C, Pani L. Immunocytochemical study of the forebrain serotonergic innervation in Sardinian alcohol-preferring rats. Psychopharmacology (Berl). 2004;172(3):341-51.

[243] Devoto P, Colombo G, Stefanini E, Gessa GL. Serotonin is reduced in the frontal cortex of Sardinian ethanolpreferring rats. Alcohol Alcohol Oxf Oxfs. 1998;33(3): 226-9.

[244] De Montis MG, et al. Sardinian alcohol-preferring rats show low 5-HT extraneuronal levels in the mPFC and no habituation in monoaminergic response to repeated ethanol consumption in the NAcS. Brain Res. 2004; 1006(1):18-27.

[245] Ciccocioppo R, Panocka I, Stefanini E, Gessa GL, Massi M. Low responsiveness to agents evoking 5-HT2 receptormediated behaviors in Sardinian alcohol-preferring rats. Pharmacol Biochem Behav. 1995;51(1):21-7.

[246] Ciccocioppo R, Angeletti S, Colombo G, Gessa G, Massi M. Autoradiographic analysis of 5-HT2A binding sites in the brain of Sardinian alcohol-preferring and nonpreferring rats. Eur J Pharmacol. 1999;373(1):13-9.

[247] Richter RM, Zorrilla EP, Basso AM, Koob GF, Weiss F. Altered amygdalar CRF release and increased anxiety-like behavior in Sardinian alcohol-preferring rats: A microdialysis and behavioral study. Alcohol Clin Exp Res. 2000;24(12):1765-72

[248] Colombo G, et al. Sardinian alcohol-preferring rats: A genetic animal model of anxiety. Physiol Behav. 1995;57(6):1181-5.

[249] Lobina C, Gessa GL, Colombo G. Anxiolytic effect of voluntarily consumed alcohol in sardinian alcoholpreferring rats exposed to the social interaction test. J Alcohol Drug Depend. 2013;01(06):132. doi:10.4172/23296488.1000132

[250] Rezvani AH, Overstreet DH, Janowsky DS. Genetic serotonin deficiency and alcohol preference in the fawn hooded rats. Alcohol Alcohol Oxf Oxfs. 1990;25(5):573-5.

[251] Rezvani AH, Overstreet DH, Janowsky DS. Drug-induced reductions in ethanol intake in alcohol preferring and Fawn-Hooded rats. Alcohol Alcohol Oxf Oxfs Suppl. 1991;1:433-7.
[252] Overstreet DH, Rezvani AH. Behavioral differences between two inbred strains of Fawn-Hooded rat: A model of serotonin dysfunction. Psychopharmacology (Berl). 1996;128(3):328-30.

[253] Overstreet DH, Rezvani AH, Parsian A. Behavioural features of alcohol-preferring rats: Focus on inbred strains. Alcohol Alcohol Oxf Oxfs. 1999;34(3):378-85.

[254] Rezvani AH, Parsian A, Overstreet DH. The FawnHooded (FH/Wjd) rat: A genetic animal model of comorbid depression and alcoholism. Psychiatr Genet. 2002;12(1):1-16.

[255] Aulakh CS, Tolliver T, Wozniak KM, Hill JL, Murphy DL. Functional and biochemical evidence for altered serotonergic function in the fawn-hooded rat strain. Pharmacol Biochem Behav. 1994;49(3):615-20.

[256] Hulihan-Giblin BA, Park YD, Aulakh CS, Goldman D. Regional analysis of 5-HT1A and 5-HT2 receptors in the fawn-hooded rat. Neuropharmacology. 1992;31(11): 1095-9.

[257] Chen F, Lawrence AJ. 5-HT transporter sites and 5HT1A and 5-HT3 receptors in fawn-hooded rats: A quantitative autoradiography study. Alcohol Clin Exp Res. 2000;24(7):1093-102.

[258] Kantor S, Graf M, Anheuer ZE, Bagdy G. Rapid desensitization of 5-HT(1A) receptors in Fawn-Hooded rats after chronic fluoxetine treatment. Eur Neuropsychopharmacol J Eur Coll Neuropsychopharmacol. 2001;11(1):15-24.

[259] Hensler JG, Hodge CW, Overstreet DH. Reduced 5-HT3 receptor binding and lower baseline plus maze anxiety in the alcohol-preferring inbred fawn-hooded rat. Pharmacol Biochem Behav. 2004;77(2):281-9.

[260] Hulihan-Giblin BA, Park YD, Goldman D, Aulakh CS. Analysis of the 5-HT1C receptor and the serotonin uptake site in fawn-hooded rat brain. Eur J Pharmacol. 1993;239(1-3):99-102.

[261] Babor TF, Dolinsky Z, Rounsaville B, Jaffe J. Unitary versus multidimensional models of alcoholism treatment outcome: An empirical study. J Stud Alcohol. 1988;49(2): 167-77.

[262] Pettinati HM, et al. Sertraline treatment for alcohol dependence: Interactive effects of medication and alcoholic subtype. Alcohol Clin Exp Res. 2000;24(7):1041-9.

[263] Babor T, Hofmann M, DelBoca FK, et al. Types of alcoholics, i: Evidence for an empirically derived typology based on indicators of vulnerability and severity. Arch Gen Psychiatry. 1992;49(8):599-608.

[264] Cloninger CR, Sigvardsson S, Bohman M. Type I and type II alcoholism: An update. Alcohol Health Res World. 1996;20(1):18-23.

[265] Gorelick DA, Paredes A. Effect of fluoxetine on alcohol consumption in male alcoholics. Alcohol Clin Exp Res. 1992;16(2):261-5.

[266] Naranjo CA, Bremner KE. Serotonin-altering medications and desire, consumption and effects of alcohol-treatment implications. EXS. 1994;71:209-19.

[267] Naranjo CA, Knoke DM. The role of selective serotonin reuptake inhibitors in reducing alcohol consumption. J Clin Psychiatry. 2001;62(Suppl 20):18-25.

[268] Naranjo CA, Sellers EM. Serotonin uptake inhibitors attenuate ethanol intake in problem drinkers. Recent Dev Alcohol Off Publ Am Med Soc Alcohol Res Soc Alcohol Natl Counc Alcohol. 1989;7:255-66.

[269] Thomas R. Fluvoxamine and alcoholism. Int Clin Psychopharmacol. 1991;6(Suppl 3):85-90; discussion 90-92. 
[270] Tiihonen J, Ryynänen OP, Kauhanen J, Hakola HP, Salaspuro M. Citalopram in the treatment of alcoholism: A double-blind placebo-controlled study. Pharmacopsychiatry. 1996;29(1):27-9.

[271] Janiri L, et al. Effects of fluoxetine at antidepressant doses on short-term outcome of detoxified alcoholics. Int Clin Psychopharmacol. 1996;11(2):109-17.

[272] Dundon W, Lynch KG, Pettinati HM, Lipkin C. Treatment outcomes in type a and $\mathrm{B}$ alcohol dependence 6 months after serotonergic pharmacotherapy. Alcohol Clin Exp Res. 2004;28(7):1065-73.

[273] Cornelius JR, et al. Preliminary report: Double-blind, placebo-controlled study of fluoxetine in depressed alcoholics. Psychopharmacol Bull. 1995;31(2): 297-303.

[274] Cornelius JR, et al. Fluoxetine in depressed alcoholics. A double-blind, placebo-controlled trial. Arch Gen Psychiatry. 1997;54(8):700-5.

[275] Cornelius JR, et al. Fluoxetine versus placebo in depressed alcoholics: A 1-year follow-up study. Addict Behav. 2000;25(2):307-10.

[276] Bruno F. Buspirone in the treatment of alcoholic patients. Psychopathology. 1989;22(Suppl 1):49-59.

[277] Kranzler HR. Evaluation and treatment of anxiety symptoms and disorders in alcoholics. J Clin Psychiatry. 1996;57(Suppl 7):15-21; discussion 22-24.

[278] Kranzler HR, et al. Buspirone treatment of anxious alcoholics. A placebo-controlled trial. Arch Gen Psychiatry. 1994;51(9):720-31.
[279] Tollefson GD, Lancaster SP, Montague-Clouse J. The association of buspirone and its metabolite 1pyrimidinylpiperazine in the remission of comorbid anxiety with depressive features and alcohol dependency. Psychopharmacol Bull. 1991;27(2):163-70.

[280] Tollefson GD, Montague-Clouse J, Tollefson SL. Treatment of comorbid generalized anxietyin a recently detoxified alcoholic population with a selective serotonergic drug (buspirone). J Clin Psychopharmacol. 1992;12(1):19-26.

[281] Martinotti G, Di Nicola M, Di Giannantonio M, Janiri L. Aripiprazole in the treatment of patients with alcohol dependence: A double-blind, comparison trial vs. naltrexone. J Psychopharmacol Oxf Engl. 2009;23(2):123-9.

[282] Myrick H, et al. The effect of aripiprazole on cue-induced brain activation and drinking parameters in alcoholics. $\mathbf{J}$ Clin Psychopharmacol. 2010;30(4):365-72.

[283] Han DH, Kim SM, Choi JE, Min KJ, Renshaw PF. Adjunctive aripiprazole therapy with escitalopram in patients with co-morbid major depressive disorder and alcohol dependence: Clinical and neuroimaging evidence. J Psychopharmacol Oxf Engl. 2013;27(3):282-91.

[284] Johnson BA, et al. Ondansetron for reduction of drinking among biologically predisposed alcoholic patients: A randomized controlled trial. JAMA. 2000;284(8):963-71.

[285] Johnson BA, Roache JD, Ait-Daoud N, Zanca NA, Velazquez M. Ondansetron reduces the craving of biologically predisposed alcoholics. Psychopharmacology (Berl). 2002;160(4):408-13. 